\title{
ZADARSKA MATICA UMRLIH 1597. - 1617.
}

\author{
Grozdana FRANOV-ŽIVKOVIĆ \\ Zavod za povijesne znanosti HAZU u Zadru \\ Zadar, Hrvatska
}

\author{
UDK: 929.532(497.5 Zadar)“1597/1617“ \\ DOI: $10.21857 /$ ygjwrcd43y \\ Izvorni znanstveni rad \\ Prihvaćeno: 26. svibanj 2021.
}

$\mathrm{Na}$ temelju podataka zabilježenih u matičnoj knjizi umrlih 1597. do 1617. u radu je napravljeno istraživanje strukture zadarskog društva preko analize pojedinih staleških grupacija (patricijat, crkvene osobe, pripadnici mletačke vojne i civilne uprave, građani, pučani) te preko analize profesionalnih grupacija (obrtnici, trgovci, vojnici, ribari, mornari, težaci i ostali). Popisana su mjesta pokopa te uzroci smrti. Napravljen je kratak pregled povijesnih prilika, kao i način vođenja matičnih knjiga nakon Tridentskog sabora.

Ključne riječi: Matična knjiga umrlih, Zadar, struktura stanovništva, mjesta pokopa, kraj 16. i poč. 17. st.

\section{KRATAK PREGLED POVIJESNIH PRILIKA U ZADRU U RAZDOBLJU OD 1597. DO 1617.}

Matica je nastala u razdoblju nakon Ciparskog rata (1570. - 1573.), tj. nakon novog razgraničenja ${ }^{1}$ koje je bilo obilježeno nemirima na mletačkoturskoj granici. ${ }^{2}$ Zabilježeni su veći upadi Osmanlija već od 1590. godine kad su došli do gradskih zidina, pa tako godine 1574. napadaju okolicu Grada, a

1 Ivna ANzulović, Razgraničenje između mletačke i turske vlasti na zadarskom prostoru 1576. godine, nakon Ciparskog rata, Zadarska smotra, 1-3, Zadar, 1998., 53 - 108.

2 Seid Traljić, Trgovina Bosne i Hercegovine s lukama Dalmacije i Dubrovnika u XVII i XVIII stoljeću, Pomorski zbornik, I dio, Zagreb, 1962., 341 - 371; Seid Traljić, Mletačko-tursko susjedstvo na zadarskoj krajini XVII. stoljeća, Radovi Instituta JAZU u Zadru, sv. 4-5, Zagreb, 1959., 409 - 424; Seid TraljIć, Zadar i turska pozadina od XV. do potkraj XIX. stoljeća, Radovi Instituta JAZU u Zadru, sv. 11-12, Zadar, 1965., 203 - 227; Seid TraLjIć, Tursko-mletačke granice u Dalmaciji u XVI. i XVII. stoljeću, Radovi Instituta JAZU u Zadru, sv. 20, Zadar, 1973., 447 458; Seid Traljić, Vrana i njezini gospodari u doba turske vladavine, Povijest Vrane, Političko, kulturno i privredno značenje Vrane kroz stoljeća, Zadar, 1971., 343 - 378; Grozdana FranovŽIvKović, Svakodnevni život na tursko-mletačkoj granici na području Zemunika u 17. st. na temelju dokumenata pisanih hrvatskom ćirilicom (bosanicom) i glagoljicom, Zemunik u prostoru i vremenu (ur. Josip Faričić, Zdenko Dundović), Zadar, 2016., 170 - 189; G. Franov-Žıv ković, Stanje na mletačko turskoj granici na području Vrane u 17. st. na temelju dokumenata pisanih hrvatskom ćirilicom (bosanicom) i glagoljicom, Braća Vranjani i vransko područje tijekom povijesti, Zadar, 2017., $411-438$. 
upadi su zabilježeni 1602., 1610., 1611., 1612. i 1613. godine. ${ }^{3}$ Drugu opasnost predstavljaju uskoci koji su na turske upade odgovarali napadima na osmansko područje, ali su često napadali i pljačkali mjesta na mletačkom području, posebno otočna, a bilo je slučajeva da su u neposrednoj blizini grada napadali i pljačkali trgovačke mletačke galije. ${ }^{4} \mathrm{Za}$ vrijeme Ciparskog rata gradske utvrde bile su dijelom oštećene pa su počeli radovi na njihovoj obnovi te su tada sagrađeni i neki novi obrambeni bastioni. ${ }^{5}$ Nakon Ciparskog rata vojnu posadu Zadra činilo je najmanje 400 vojnika te određen broj časnika, a posada je najčešće bila razvrstana u pet satnija na čelu kojih je bio kapetan. Posadu je činio i određen broj topnika (bombardijera), čiji je broj ovisio o potrebi. ${ }^{6} \mathrm{U}$ gradu nije postojala prava vojarna, već su vojnici bili smješteni po privatnim kućama. Do 1614. u središtu je grada postojalo malo logorište (kvartir), koje je tada porušeno. Nekoliko godina kasnije u gradu je napravljen kvartir za vojsku i konje, u kojem se znalo smjestiti i do 3000 vojnika, a za potrebe vojske se upotrebljavao i lazaret sv. Marka. ${ }^{7}$

Stvarnu vlast u gradu imali su knez i kapetan. Knez je upravljao civilnim i sudskim poslovima, dok je kapetan bio zadužen za vojne poslove. ${ }^{8} \mathrm{O}$ novčanim

3 Tomislav Raukar, Ivo Petricioli, Franjo Švelec, Šime Peričić, Zadarpod mletačkom upravom, Zadar, 1987., 356, 357.

4 T. Raukar, I. Petricioli, F. Švelec, Š. Peričić, Zadarpod mletačkom upravom, 356, 357; AmosRube FILIPI, Uskočki podvig kod Mulina na otoku Ugljanu, Zadarska revija, III, br. 2, Zadar, 1954. 142 - 153; Amos Rube Filipi, Senjski uskoci i zadarsko otočje, Pomorski zbornik, knj. 2, Zadar, 1964., $579-632$.

5 T. Raukar, I. Petricioli, F. Švelec, Š. Peričić, Zadar pod mletačkom upravom, 358; Angelo Benvenuti, Storia di Zara (dal 1409-1797), Milano, 1944., 127.

6 T. Raukar, I. Petricioli, F. Švelec, Š. Peričić, Zadarpod mletačkom upravom, 359, 406. Topnici su se skupljali u Bratovštini sv. Barbare, od 1615. njezini članovi obavljaju i funkciju gradskih vatrogasaca. U Zadru su funkciju vatrogasaca imali bratimi Bratovštine sv. Antuna opata. Vladislav Cvitanović, Bratovštine grada Zadra, Zbornik Zadar, Zagreb, 1964., 457 - 470; Grozdana FrANov-Žıv Ković, Glagoljica u Zadru - Glagoljski zapisi iz knjige bratovštine sv. Antuna opata 1725.-1777., Glasilo Udruge glagoljaša Zadar Slovo Rogovsko, Zadar, 2016., br. 4, 13 - 16; C. F. Bianchi, Fasti di Zara, Religioso-politico-civili, dall'anno 1184 Ar. Cr. Sino all' Anno 1888, Zadar, 1888., 80 i 82; Lovorka Čoralić, Hrvatski useljenici u Mlecima, Bratovština topnika i kotorski biskup Angelo Baronio, Povijesni prilozi, 32, Zagreb, 2013., 44, 169 - 181; Lovorka Čoralić, Izvori i literatura o bratovštinama u Dalmaciji od srednjeg vijeka do pada Mletačke Republike, Croatica Christiana periodica, 15, br. 27, Zagreb, 1991., 88 - 96.

7 T. Raukar, I. Petricioli, F. Švelec, Š. Peričić, Zadarpod mletačkom upravom, 359; F. Bianchi, Fasti di Zara, Religioso-politico-civili, dall'anno 1184 Ar. Cr. Sino all' Anno 1888, Zadar, 1888.

8 T. Raukar, I. Petricioli, F. Švelec, Š. Peričić, Zadar pod mletačkom upravom, 366; Maja Novak-SAmbrailo, Matrikula bratovštine sv. Jakova iz Galicije u Zadru, Radovi Instituta JAZU u Zadru, Zagreb, 1972., 5 - 31; Maja Novak-SAmbraIlo, Plemići, građani i pučani u Zadru (XVXVII st.), Radovi Zavoda za povijesne znanosti HAZU u Zadru, 19, Zadar, 1972., 167 - 186; Maja Novak, Zadar glavni grad Mletačke Dalmacije i Albanije, Radovi Instituta HAZU u Zadru, 11-12, Zadar, 1965., 119 - 199; Roman JeLIĆ, Stanovništvo Zadra u drugoj polovici XVI i početkom XVII stoljeća gledano kroz matice vjenčanih, Starine, Zagreb, 1959., 349 - 509. 
poslovima grada brinuo se rizničar (kamerlengo), a najčešće je njegova funkcija bila povezana s funkcijom kaštelana. ${ }^{9} \mathrm{Od}$ kraja 16. st. u Zadru stoluje i generalni providur za Dalmaciju i Albaniju, tj. za područje od Raba do Ulcinja. ${ }^{10} \mathrm{U}$ gradu je postojalo Plemićko vijeće, koje nije imalo stvarne ovlasti, već je imalo mogućnost organizacije svečanosti, dočeka, procesija, dobrotvornih zaklada i slično, oko čega se sporilo s pučanima. Pučani su imali svoju skupštinu (Bratovštinu sv. Jakova), ${ }^{11}$ a na sjednicama Plemićkog vijeća i skupštine pučana prisustvovao je gradski knez. ${ }^{12} S$ vremenom su neki pučani stekli znatan imetak pa nastaje novi sloj između plemića i pučana - pučani-građani. ${ }^{13}$

Sudstvo nije bilo odvojeno od uprave. Prvu sudbenu instancu u kaznenom i građanskom postupku vodio je knez, uz pasivno prisustvo predstavnika gradskog plemstva. Drugu instancu predstavljao je generalni providur, točnije Generalni sud. Sporovi su se katkad rješavali i u Mletcima. ${ }^{14}$

Broj stanovnika u ovom razdoblju kretao se oko pet do šest tisuća. Godine 1596. bio je 5814,1598 . godine 5390 , a 1608 . godine $5200 .{ }^{15}$ Većina stanovnika bila je domaćeg (hrvatskog) podrijetla. ${ }^{16}$

Tijekom Ciparskog rata mnoge su kuće u gradu bile oštećene, a oko 1600. godine trećina je zgrada bila nenaseljena. Nove kuće gradile su se uglavnom od kamena. Kad je srušeno predgrađe Varoš 1566. godine, ${ }^{17}$ stanovnici su preseljeni u predio zvan Babe, južno od Citadele. Tada je Varoš bio izgrađen većinom drvenim kućama, a nakon doseljenja Varošana više je bilo izgrađenih kamenih kuća. ${ }^{18}$

9 T. Raukar, I. Petricioli, F. Švelec, Š. Peričić, Zadar pod mletačkom upravom, 366; Roman JeLIĆ, Stanovništvo Zadra u drugoj polovici XVI i početkom XVII stoljeća gledano kroz matice vjenčanih, Starine, Zagreb, 1959., 349 - 509.

10 T. Raukar, I. Petricioli, F. Švelec, Š. Peričić, Zadar pod mletačkom upravom, 366.

11 Maja Novak-Sambrailo, Matrikula bratovštine sv. Jakova iz Galicije u Zadru, 5 - 31.

12 T. Raukar, I. Petricioli, F. Švelec, Š. Peričić, Zadar pod mletačkom upravom, 366.

13 T. Raukar, I. Petricioli, F. Švelec, Š. Peričić, Zadar pod mletačkom upravom, 399; Maja Novak-Sambrailo, Plemići, građani i pučani u Zadru (XV-XVII st.), 177.

14 T. Raukar, I. Petricioli, F. Švelec, Š. Peričić, Zadar pod mletačkom upravom, 369.

15 Roman Jelić, Stanovništvo Zadra 1608. godine, Zadar, 1985., 108; Roman Jelić, Stanovništvo Zadra u drugoj polovici XVI i početkom XVII stoljeća gledano kroz matice vjenčanih, Starine, Zagreb, 1959., 355, bilj. 35; Roman Jelić, Zdravstvo u Zadru i njegovu području, Zadar, 1978., 55 bilj. 69, 71; T. Raukar, I. Petricioli, F. Švelec, Š. Peričić, Zadar pod mletačkom upravom, 371.

16 R. Jelić, Stanovništvo Zadra u drugoj polovici XVI i početkom XVII stoljeća gledano kroz matice vjenčanih, 349 - 509; T. Raukar, I. Petricioli, F. Švelec, Š. Peričić, Zadar pod mletačkom upravom, 400; Nikola ČolaK, Naše ribarstvo do pada Mletačke Republike, Pomorski zbornik, I i II, Zadar, 1962.

17 Zdenko Dundović, Bratovština zadarskih Varošana, Zadar, 2020.

18 T. Raukar, I. Petricioli, F. Švelec, Š. Peričić, Zadar pod mletačkom upravom, 282, 283. 
Od 16. stoljeća postoji vojna bolnica kojom je upravljao prior. Vojna bolnica se od 16. stoljeća selila najprije iz tvrđave Citadella, zatim se 1515. nalazila kod Samostana sv. Nikole, a za vrijeme Ciparskog rata (1570. - 1573.) prebačena je na mjesto kod današnje gradske tržnice. ${ }^{19}$ Bolnica za kažnjenike i galiote, osnovana kad i ona za vojnike u 16. st., nalazila se u Kaštelu. Izgorjela je 1604., a 1605. ponovno je otvorena. ${ }^{20}$ Nahodište je bilo obnovljeno 1605., a njime su upravljala dva priora, jedan plemić, a drugi građanin, poslugu su činile priorica i nekoliko dadilja. ${ }^{21} \mathrm{Na}$ popisu 1608. godine spominje se šest hospitala: sv. Bernadina, sv. Jakova, sv. Marka, Gospe od Varoša, Gospe od kaštela i hospital za osuđenike (vjerojatno ovaj za vojnike, kažnjenike i galiote). ${ }^{22} \mathrm{U}$ matici umrlih spominje se hospital sv. Donata, sv. Marka, sv. Bernardina, Madona de Borgo te hospital delle militia (1607.).

Zbog raznih epidemija zaraznih bolesti, prvenstveno kuge, u gradu su građeni lazareti. Spominje se lazaret na otočiću sv. Klimenta, predgrađu sv. Martina i lazaret sv. Luke kod Gospe Maslinske. Lazaret sv. Marka bio je otvoren za turske karavane i spominje se 1610. godine, a jedan sličan lazaret postojao je i na Puntamici. ${ }^{23}$ Postojao je i lazaret gubavaca sv. Duha ili bolnica sv. Lazara, koji je srušen 1570. godine skupa s predgrađima, pa se guba, koja se pojavljivala rijetko, liječila po privatnim kućama. ${ }^{24}$

U razdoblju pisanja ove matične knjige u Zadru nije zabilježena epidemija kuge, dok se u mjestima zadarske okolice kuga pojavljivala 1607./1608. i 1610. godine. ${ }^{25}$ Godine 1607. pojavila se kuga u Splitu. ${ }^{26}$ Jelić spominje pojavu kuge

19 T. Raukar, I. Petricioli, F. Švelec, Š. Peričić, Zadar pod mletačkom upravom, 405; R. Jelić, Zdravstvo u Zadru i njegovu podrućju, 24.

20 R. Jelić, Zdravstvo u Zadru i njegovu području, 25.

21 T. Raukar, I. Petricioli, F. Švelec, Š. Peričić, Zadar pod mletačkom upravom, 406; Roman JeLIć, Zadarsko nahodište, Radovi Instituta JAZU u Zadru, 10, Zadar, 1963., 213 - 289; R. JeLIć, Zdravstvo u Zadru i njegovu području, 23.

22 R. Jelić, Stanovnišstvo Zadra 1608. godine, 115. R. JeLIĆ, Zdravstvo u Zadru i njegovu području, 12 - 17. Jelić spominje do 19. stoljeća 34 hospitala u Zadru. Početkom 17. stoljeća otvoren je lazaret sv. Marka za smještaj turskih trgovaca i njihove robe. T. Raukar, I. Petricioli, F. Švelec, Š. PERIČIĆ, Zadar pod mletačkom upravom, 405.

23 R. Jelić, Zdravstvo u Zadru i njegovu području, 19 - 22.

24 R. Jelić, Zdravstvo u Zadru i njegovu području, 23.

25 G. Franov-Žıv ković, Glagoljske matice umrlih župe Rođenje blažene djevice Marije u Pašmanu 1606. - 1825., u: P. Kero, G. Franov-Žıv ković, M. Kero, Glagoljske matice umrlih župe Rođenje blažene djevice Marije u Pašmanu 1606. - 1825., VII - XXXII, Zadar, 2015.; P. Kero, G. FranovŽIv ković, M. Kero, Glagoljske matice umrlih župe Rođenje blažene djevice Marije u Pašmanu 1606. - 1825., ur. Pavao Kero, Josip Faričić, Zadar, 2015.; Pavao Kero, Popis glagoljskih kodeksa Zadarske nadbiskupije, 2. izdanje, Zadar, 2015.; HR-DAZD, Pašman, Glagoljska matica umrlih 1606. - 1679.; Pašman, Glagoljska matica umrlih 1607. - 1612.; Pašman, Glagoljska matica umrlih 1607. - 1612. 
1610. godine u Zemuniku i Vrani koji su tada bili u turskim rukama. Zahvaljujući mjerama opreza (mletačkih vlasti) kuga se nije proširila na Zadar. ${ }^{27}$

U ovom razdoblju nisu zabilježene epidemije drugih zaraznih bolesti, iako Sabalich pretpostavlja da je uzrok velikom broju umrlih na lađi kapetana Todinija i još nekoliko brodova neka epidemija. ${ }^{28}$ Župnici uglavnom nisu bilježili od čega je neka osoba umrla, osim u pojedinim slučajevima kad je osoba umrla nasilnom smrću, tj. bila ubijena ili obješena.

\section{O MATICI UMRLIH 1597. - 1617.}

Zadarske matične knjige nisu sustavno obrađivane. Jedino su obrađene tri matice vjenčanih iz razdoblja od 15. 1. 1576. do 20.6. 1613. koje je objavio Jelić. ${ }^{29}$ Matice umrlih dotakao je u svom radu Giuseppe Sabalich, ali s naglaskom na istraživanja mjesta pokopa te je iz svih matica umrlih, pa i ove prve, vadio podatke koji su mu bili zanimljivi. ${ }^{30}$ Iz ovog razdoblja obrađen je popis stanovnika iz 1608. godine. ${ }^{31} \mathrm{Iz}$ ranijeg razdoblja postoji popis stanovnika iz $1527 . .^{32}$

Matica umrlih 1597. - 1617. narativno je pisana matična knjiga otvorena nakon Tridentskog koncila (1545. - 1563.). ${ }^{33}$ Ovo nije najranije sačuvana matica

Prema ovim matičnim knjigama vidimo da je 1606., 1607. i 1608. godine u Pašmanu bila epidemija kuge; Biserka BeliCzA, Medicina i zdravstvo, u: Hrvatska i Europa, kultura, znanost i umjetnost, sv. III, Barok i prosvjetiteljstvo (XVII. - XVIII .st.), ur. Ivan Golub, Zagreb, 2013., 379 - 403; R. JELIĆ, Zdravstvo u Zadru i njegovu podrućju; Roman Jelić, Zdravstvo na zadarskim otocima, Zadarsko otočje, ur. Valentin Uranija, Zadar, 1974., 579 - 619. Da je ovih godina na zadarskom području vladala zaraza kugom vidljivo je po zapisima, ali i kroz povećanje smrtnosti u sukošanskim maticama. Pavao Kero, G. Franov-ŽIvković, Marija Kero, Dvije sukošanske matične knjige umrlih 1608. do 1759., Monumenta glagolitica Archidioecesis Iadertianae, Monumenta glagolitica Archidioecesis Iadertianae, ur. Pavao Kero, Josip Faričić, Zadar, 2018., 7 - 23.

26 B. BELICZA, Medicina i zdravstvo, 379 - 403.

27 R. Jelić, Zdravstvo u Zadru i njegovu području, 19; G. Franov-ŽIvković, Svakodnevni život na tursko-mletačkoj granici na području Zemunika u 17. st., 170 - 189; Carlo F. BIANCHI, Fasti di Zara, Religioso-politico-civili, dall'anno 1184 Ar. Cr. Sino all'Anno 1888, Zadar, 1888.

28 Giuseppe SABALICH, Curiositá storiche Zaratine, Zadar, 1906., 164.

29 R. JELIĆ, Stanovništvo Zadra u drugoj polovici XVI i početkom XVII stoljeća gledano kroz matice vjenčanih, 349 - 509. Riječ je o ovim maticama koje se nalaze u Arhivu Zadarske nadbiskupije: I. Matica vjenčanih 1576. - 1593.; II Matica vjenčanih 1593. - 1604.; i III Matica vjenčanih 1604. 1613.

30 G. SABALICH, Curiositá storiche Zaratine, poglavlje I Libri dei morti, 147 - 193.

31 R. JELIĆ, Stanovništvo Zadra 1608. godine.

32 Šime Ljubić, Commissiones et relationes Venetae, 1433-1527., tom I, Zagreb, 1876., 194 - 223 ; Domagoj Madunić, Mjera grada: Zadarski popis stanovništva 1527. godine, Povijesni prilozi, 36, Zagreb, 2009., 23 - 62.

33 HR-AZDN, I, Zadar, Matična knjiga umrlih 1597. - 1617. 
na zadarskom području jer je sačuvana matična knjiga krštenih Sv. Stošije u Zadru od 1569. do 1580. te niz glagoljskih matičnih knjiga, kao što su Olipska matica krštenih 1565. - 1613., ${ }^{34}$ Silbenska matica krštenih, vjenčanih, umrlih i krizmanih 1565. - 1622. (koja je nakon Cvitanovićeva popisa zagubljena), Olipska matica vjenčanih 1566. - 1613., ${ }^{35}$ Molatska matica krštenih, vjenčanih, umrlih i krizmanih 1579. - 1650., Ugljanska matica krštenih 1580. - 1599., ${ }^{36}$ Pašmanska matica krštenih, vjenčanih, umrlih, krizmanih, ispovijedanih i pričešćenih 1582. - 1596., ${ }^{37}$ Matica krštenih iz Banja 1587. - 1613., Lukoranska matica krštenih 1590. - 1613. ${ }^{38}$ i Olipska knjiga pričešćenih iz $1595 .{ }^{39}$

Za zadarsko područje nisu sačuvane matične knjige pisane prije Tridentskog koncila, kao npr. u Istri. ${ }^{40}$

Za razliku od tabelarnih matičnih knjiga (uvedenih od 1816., odnosno na zadarskom području od 1825.), gdje su određene rubrike koje župnik mora popunjavati pri upisima činjenica rođenja (krštenja), vjenčanja ili smrti, kod narativno pisanih matica takve rubrike ne postoje, a župnik upisuje tek nekoliko nužnih podataka, tako da više sliče nekim popisima umrlih.

Nakon Tridentskog koncila nisu odmah bili prepisani obrasci (forme) upisa, koji su doneseni tek po Rimskom obredniku 1614. godine.

Forma (obrazac) za upise u maticu umrlih glasi ovako:

Godine Gospodnje, dana, mjeseca je u otkrilju svete matere crkve svoju dusu Bogu izrudio (predao) N. sin ili kći N. i N. (ili zakonita žena N.) u starosti ..., u ulici, u kući. ..., njegovo tijelo bi pokopano dana ..... na pokapalište (groblje) crkve sv..... ja

34 Analiza, faksimil i transliteracija ove glagoljske matice objavljeni su u nizu Monumenta glagolitica Archidioecesis Iadertinae. Pavao Kero, Grozdana Franov-ŽIvković, Pet glagoljskih matica krštenih župe Uznesenja B. D. M. na Olibu 1565.-1668., Zadar, 2011.

35 Analiza, faksimil i transliteracija ove glagoljske matice objavljeni su u nizu Monumenta glagolitica Archidioecesis Iadertinae. Pavao Kero, Grozdana Franov-ŽIvković, Četiri glagoljske matice vjenčanih župe Uznesenja B. D. M. na Olibu 1566. - 1681., Zadar. 2011.

36 Transliteracija objavljena u članku G. Franov-ŽIvković, Načini evidentiranja podataka u glagoljskim matičnim knjigama pisanima do 1825. godine na zadarskom području, Povijesni zbornik - godišnjaku za kulturu i povijesno naslijeđe, br. 4 (God. III), Osijek, 2009., 79 - 124.

37 Analiza, faksimil i transliteracija samo glagoljske matice umrlih objavljeni su u nizu Monumenta glagolitica Archidioecesis Iadertinae. P. Kero, G. Franov-ŽIvković, M. Kero, Glagoljske matice umrlih župe Rođenje blažene djevice Marije u Pašmanu 1606. - 1825., (ur. Pavao Kero i Josip Faričić), Zadar, 2015.

38 Transliteracija matice objavljena u članku Grozdana FrANov-ŽIVković, Lukoranski glagoljski kodeksi, Glasilo Udruge glagoljaša Zadar Slovo Rogovsko, br. 3, Zadar, 2015., 12 - 16.

39 Pavao Kero, Popis glagoljskih kodeksa zadarske nadbiskupije, 2. izdanje, Zadar, 2015., 49.

40 Najstarija matična knjiga na istarskom području je matica krštenih je iz Župe Umag iz 1483., a matica krštenih Župe Labin je iz 1536. Tea RADolA, Stanovništvo Barbana u matičnim knjigama XIX. stoljeća, diplomski rad, Sveučilište u Puli, Pula, 2016. 
sam ga ispovidao ili potvrdeni (ovlašteni) ispovjednik dana ......., podijelio sam mu svetu poputbinu dana ... i sveto posljednje pomazanje dana... . ${ }^{41}$

Neke starije glagoljske knjige imaju obrazac na koricama ispisan latinskim jezikom, talijanskim jezikom ili glagoljicom.

Nažalost, ni nakon propisivanja obrasca 1614. godine zadarske matične knjige nisu vođene na ispravan način, tako da smo uskraćeni za mnoge zanimljive podatke poput godina starosti, adrese stanovanja, a mnogima nije upisano ime roditelja. Mnogi svećenici u ostalim mjestima zadarskog područja u matične su knjige umrlih dodavali uzroke smrti. U zadarskim maticama imamo samo katkad upisane nasilne smrti, dok ostali uzroci, poput smrti uslijed zaraznih bolesti, nisu upisani. Zbog nedostatka podataka o godinama starosti ne može se procijeniti jesu li u ovu maticu upisivana i djeca ispod deset godina starosti i mrtvorođenčad ili se i u Zadru za njih vodila posebna matična knjiga, kao u nekim okolnim mjestima. ${ }^{42}$

U nekim seoskim glagoljskim maticama nalazimo podatke o tome da su kažnjavani oni župnici koji nisu poštivali ovaj obrazac pa su bili prisiljeni ispravno voditi matične knjige. ${ }^{43}$

U pašmanskoj matici umrlih na str. 59 nalazi se opomena koju je dao zadarski nadbiskup župniku don Boži Stagličiću. Zapis na latinskom jeziku nastao je prilikom kanonskih vizitacija 17. listopada 1659.: Pregledavši matične knjige, nadbiskup je uočio da župnik ne vodi matice po obrascu (formuli) koji je propisan Ritualom rimskim, te mu je naredio da u roku od mjesec dana te upise sredi jer će u protivnom morati platiti 10 dukata. Župnikovi su upisi doista bili prešturi, u njima su nedostajali osnovni podatci; upisivao je samo nadnevak smrti, ime i prezime osobe i mjesto ukopa. Ali, unatoč nadbiskupovoj naredbi, don Bože Stagličić je i dalje vodio matice na stari način. ${ }^{44}$

Sličan slučaj nalazimo u ovim zadarskim maticama umrlih. Ne zna se je li župnik bio kažnjavan, ali su se zadarske matice i dalje vodile na stari način.

41 G. Franov-Žıv Ković, Načini evidentiranja podataka u glagoljskim matičnim knjigama pisanima do 1825. godine na zadarskom području, 85 - 86; Ante STRGAČIĆ, Inventar fonda matičnih knjiga Državnog arbiva u Zadru, Predgovor Inventarnoj knjizi; Skupnost arbivov Slovenije Vodniki I zvezek; Vodnik po matičnih knjigah za območje SR Slovenije, Ljubljana, 1972., LXII.

42 HR-DAZD, Glagoljska matica umrlib Sutomišcica 1765. do 1825. Župnik je s druge strane matice vodio poseban popis umrle djece u razdoblju od 1.9.1767. do 9. 10. 1824.

43 HR-DAZD, Olib, Glagoljska matica krštenih 1652. - 1662.; P. Kero, Popis glagoljskih kodeksa zadarske nadbiskupije, 2. izdanje, 45 - 46: Na str. 20 je bilješka iz god. 1658. na latinskom jeziku: Treba pisati točnije formu upisa krštenja pod globu 3 libre za svaki nepravilni upis.

44 Grozdana Franov-Žıvković, Glagoljske matice umrlih župe Rođenje blažene djevice Marije u Pašmanu 1606. - 1825., u: P. Kero, G. Franov-Žıvković, M. Kero, Glagoljske matice umrlih župe Rođenje blažene djevice Marije u Pašmanu 1606. - 1825., XIII. 
Ova matična knjiga umrlih od 1597. do 1617. sadrži samo ime i prezime umrle osobe (katkad nema ni ovog podatka), datum kad je umrla te gdje je pokopana. Pored imena se samo katkad upisuje zanimanje, najčešće vojnicima (kojima je često upisana i jedinica u kojoj služe), posebno su obilježavani svećenici i redovnice, rijetko je upisan stalež, tako da rijetko kojem pripadniku plemstva imamo zapisano da je riječ o knezu $(\text { conte })^{45}$ ili nobile. Katkad je upisano zanimanje kakvom obrtniku. Katkad je upisan i poneki uzrok smrti, a nije poznat ni podatak o svećeniku koji je pravio upise u maticu, nije se potpisao ni na jednom mjestu, dok je rijetko upisano ime svećenika koji je vodio pogreb. Nisu bilježene ni godine starosti umrle osobe, tek je u dva slučaja svećeniku bilo zanimljivo da je osoba navršila sto godina: Donna Stricha, žena stradiota Chiamata Copixa passara cento anni (31. 8. 1602.); Dorothea vechia passara cento anni (11. 1. 1605.)

Unatoč ovakvim upisima, matica je prebogata podatcima, tako da u samom članku nije moguće napraviti cjelovitu analizu svih podataka npr. za vojnike (veliki broj vojnih posada, odakle dolaze vojnici i časnici, klasna struktura vojnika i časnika, vojne službe, u kojim dijelovima grada su smješteni, usporedba $s$ već objavljenim popisima 1527. i 1608. godine te maticama vjenčanih i nakon obrade maticama krštenih i slično), ili obrtnike, ili svećenike, već će se izrađene tablice upotrijebiti za nove analize i nove članke.

Plemići su upisivani sa skraćenim titulama ser (sior), donna, madonna, El clarissimo sior, El magnifico sior, siora i sl. Obrtnici su upisivani kao meser, maestro, mistro i sl., svećenici kao revendissimo, reverendissimo monsignor, prete, don i sl., a vojni časnici magnifico capo, strenuo i $\mathrm{sl}^{46}$

U matici su od ožujka 1597. do kraja lipnja 1617. upisane 3162 osobe s tim da je u nekoliko slučajeva na jedan upis upisano više osoba odjedanput pa se broj umrlih ne poklapa s brojem upisa. Od ukupnog broja upisanih 1795 umrlih su muškarci, a 1360 žene, dok se u 7 upisa ne može procijeniti je li riječ o muškoj ili ženskoj osobi jer su upisi nedovršeni ili nepotpuni. Najviše je smrti bilo 1598. godine, 239, od čega je u vremenu od 24. rujna do 3. studenog umrlo 16 osoba iz jedinice kolonela Pecaronija. Sabalich donosi da je riječ o nekoj zaraznoj bolesti. ${ }^{47}$ Najmanje upisa je u 1611. godini, samo 90.

45 Npr. knezovi Posedarski katkad su upisivani kao conte, a u većini slučajeva nije uopće upisivana titula u maticu.

46 Vidi slično D. Madunić, Mjera grada: Zadarski popis stanovništva 1527. godine, 36.

47 G. SABALICH, Curiositá storiche Zaratine, poglavlje I Libri dei morti, 164. 
TABLICA 1. Broj umrlih po godinama, mjesecima i spolu (Izvor: HR-AZDN, I, Zadar, Matična knjiga umrlih 1597. - 1617. $)^{48}$

\begin{tabular}{|c|c|c|c|c|c|}
\hline Godina upisa & Mjesec & Ukupno & Muški & Ženski & Nepoznato \\
\hline \multirow[t]{10}{*}{1597.} & $\mathrm{III}^{49}$ & 6 & 3 & 3 & \\
\hline & IV & 13 & 8 & 5 & \\
\hline & $\mathrm{V}$ & 6 & 4 & 2 & \\
\hline & VI & 14 & 10 & 4 & \\
\hline & VII & 11 & 9 & 2 & \\
\hline & VIII & 38 & 21 & 17 & \\
\hline & IX & 26 & 15 & 11 & \\
\hline & $\mathrm{X}$ & 22 & 14 & 8 & \\
\hline & $\mathrm{XI}^{50}$ & 21 & 12 & 9 & \\
\hline & XII & 23 & 16 & 7 & \\
\hline Ukupno 1597. & I-XII & 180 & 112 & 68 & - \\
\hline \multirow[t]{12}{*}{1598.} & $\mathrm{I}$ & 13 & 11 & 2 & \\
\hline & II & 21 & 11 & 10 & \\
\hline & III & 30 & 19 & 11 & \\
\hline & IV & 34 & 18 & 16 & \\
\hline & $\mathrm{V}$ & 16 & 10 & 6 & \\
\hline & VI & 13 & 7 & 6 & \\
\hline & VII & 24 & 15 & 9 & \\
\hline & VIII & 22 & 11 & 11 & \\
\hline & IX & $17+2$ & $10+2^{51}$ & 7 & \\
\hline & $\mathrm{X}$ & $14+10$ & $12+10^{52}$ & 2 & \\
\hline & $\mathrm{XI}^{53}$ & 17 & 14 & 3 & \\
\hline & XII & 6 & 4 & 2 & \\
\hline Ukupno 1598. & I-XII & 239 & 154 & 85 & - \\
\hline \multirow[t]{5}{*}{1599.} & $\mathrm{I}$ & 19 & 16 & 3 & \\
\hline & II & 9 & 7 & 2 & \\
\hline & III & 17 & 11 & 6 & \\
\hline & IV & 14 & 9 & 5 & \\
\hline & $\mathrm{V}$ & 9 & 3 & 6 & \\
\hline
\end{tabular}

48 Sve tablice i grafikoni u ovom radu napravljeni su na temelju podataka iz HR-AZDN, I, Zadar, Matična knjiga umrlih 1597. - 1617.

49 Matična knjiga otvorena je (započeti upisi) 23. ožujka 1597.

50 Dana 12. 11. 1597. na jedan upis upisana su dva vojnika kapetana Collana Todinija: Francesco de Goritia i Giombatta Bernandin da Milan.

51 Dva vojnika kapetana Todinija naknadno upisana nakon 6.11.

52 Deset vojnika kapetana Todinija naknadno upisani nakon 6.11.

53 Nakon 6. 11. naknadno je upisano 13 vojnika kolonela Pacaronija, koji su umrli u razdoblju od 24.9. do 3. 11. Od ovih naknadno upisanih, dva su umrla u rujnu, deset u listopadu i jedan u studenome. Još tri vojnika kolonela Pacaronija redovno su upisana u studenome. Dakle, u razdoblju od rujna do studenog ukupno je iz ove postrojbe umrlo 16 vojnika. 


\begin{tabular}{|c|c|c|c|c|c|}
\hline & VI & 8 & 7 & 1 & \\
\hline & VII & 9 & 6 & 3 & \\
\hline & VIII & 17 & 13 & 4 & \\
\hline & IX & 10 & 6 & 4 & \\
\hline & $\mathrm{X}$ & 9 & 6 & 3 & \\
\hline & $\mathrm{XI}$ & 27 & 18 & 9 & \\
\hline & XII & 24 & 18 & 5 & $1^{54}$ \\
\hline Ukupno 1599. & I-XII & 172 & 120 & 52 & 1 \\
\hline \multirow[t]{12}{*}{1600.} & $\mathrm{I}$ & 24 & 17 & 7 & \\
\hline & II & 8 & 4 & 4 & \\
\hline & III & 6 & 4 & 2 & \\
\hline & IV & 16 & 10 & 6 & \\
\hline & $\mathrm{V}$ & 11 & 7 & 4 & \\
\hline & VI & 5 & 1 & 4 & \\
\hline & VII & 8 & 5 & 2 & 1 \\
\hline & VIII & 8 & 4 & 4 & \\
\hline & IX & 16 & 14 & 2 & \\
\hline & $\mathrm{X}$ & 33 & 20 & 13 & \\
\hline & $\mathrm{XI}$ & 45 & 22 & 23 & 1 \\
\hline & XII & 30 & 10 & 20 & \\
\hline Ukupno 1600. & I-XII & 210 & 118 & 91 & - \\
\hline \multirow[t]{12}{*}{1601.} & $\mathrm{I}$ & 18 & 9 & 9 & \\
\hline & II & 6 & 5 & 1 & \\
\hline & III & 12 & 6 & 6 & \\
\hline & IV & 8 & 5 & 3 & \\
\hline & $\mathrm{V}$ & 14 & 7 & 7 & \\
\hline & VI & 5 & 2 & 3 & \\
\hline & VII & 8 & 5 & 3 & \\
\hline & VIII & 18 & 7 & 11 & \\
\hline & IX & 25 & 13 & 12 & \\
\hline & $\mathrm{X}$ & 18 & 9 & 9 & \\
\hline & $\mathrm{XI}$ & 15 & 6 & 9 & \\
\hline & XII & 5 & 4 & 1 & \\
\hline Ukupno 1601. & I-XII & 152 & 78 & 74 & - \\
\hline \multirow[t]{7}{*}{1602.} & I & 5 & 3 & 2 & \\
\hline & II & 9 & 3 & 6 & \\
\hline & III & 12 & 8 & 4 & \\
\hline & IV & 16 & 11 & 5 & \\
\hline & $\mathrm{V}$ & 14 & 7 & 7 & \\
\hline & VI & 6 & 3 & 3 & \\
\hline & VII & 7 & 2 & 5 & \\
\hline
\end{tabular}

54 Nepoznato - nedovršeni ili nepotpuni upisi. 


\begin{tabular}{|c|c|c|c|c|c|}
\hline & VIII & 8 & 3 & 5 & \\
\hline & IX & 19 & 13 & 6 & \\
\hline & $\mathrm{X}$ & $12^{55}$ & 9 & 3 & \\
\hline & $\mathrm{XI}$ & $14+1$ & $6+1^{56}$ & 8 & \\
\hline & XII & 8 & 5 & 3 & \\
\hline Ukupno 1602. & I-XII & 131 & 74 & 57 & - \\
\hline \multirow[t]{12}{*}{1603.} & $\mathrm{I}$ & 13 & 8 & 5 & \\
\hline & II & 10 & 5 & 5 & \\
\hline & III & 10 & 6 & 4 & \\
\hline & IV & 12 & 8 & 4 & \\
\hline & $\mathrm{V}$ & 4 & 3 & 1 & \\
\hline & VI & 7 & 2 & 5 & \\
\hline & VII & 4 & 3 & 1 & \\
\hline & VIII & 12 & 7 & 5 & \\
\hline & IX & $19^{57}$ & 12 & 7 & \\
\hline & $\mathrm{X}$ & 15 & 7 & 8 & \\
\hline & $\mathrm{XI}$ & 17 & 4 & 13 & \\
\hline & XII & 12 & 4 & 8 & \\
\hline Ukupno 1603. & I-XII & 135 & 69 & 66 & - \\
\hline \multirow[t]{12}{*}{1604.} & I & 5 & 1 & 4 & \\
\hline & II & 11 & 4 & 7 & \\
\hline & III & 8 & 5 & 3 & \\
\hline & IV & 6 & 4 & 2 & \\
\hline & V & 5 & 2 & 3 & \\
\hline & VI & 5 & 1 & 4 & \\
\hline & VII & 5 & 4 & 1 & \\
\hline & VIII & 8 & 5 & 3 & \\
\hline & IX & 14 & 8 & 6 & \\
\hline & $\mathrm{X}$ & 15 & 8 & 7 & \\
\hline & $\mathrm{XI}$ & 16 & 11 & 5 & \\
\hline & XII & 9 & 3 & 6 & \\
\hline Ukupno 1604. & I-XII & 107 & 56 & 51 & - \\
\hline \multirow[t]{8}{*}{1605.} & I & 14 & 8 & 6 & \\
\hline & II & 7 & 4 & 3 & \\
\hline & III & 3 & 1 & 2 & \\
\hline & IV & - & - & - & \\
\hline & $\mathrm{V}$ & 2 & 1 & 1 & \\
\hline & VI & 8 & 3 & 5 & \\
\hline & VII & 11 & 7 & 4 & \\
\hline & VIII & 22 & 10 & 12 & \\
\hline
\end{tabular}

55 Na jednom upisu su Grgo i Mate Margetić iz Bibinja - pogubljeni.

56 Jedna osoba upisana naknadno u 12 mjesecu.

$57 \mathrm{Na}$ jednom upisu su Domenigo Šibenčan i pet kolega koji su obješeni. 


\begin{tabular}{|c|c|c|c|c|c|}
\hline & IX & 11 & 5 & 6 & \\
\hline & $\mathrm{X}$ & $10^{58}$ & 6 & 4 & \\
\hline & $\mathrm{XI}$ & 15 & 9 & 6 & \\
\hline & XII & 9 & 8 & 1 & \\
\hline Ukupno 1605. & I-XII & 112 & 62 & 50 & - \\
\hline \multirow[t]{12}{*}{1606.} & $\mathrm{I}$ & 8 & 5 & 3 & \\
\hline & II & 11 & 8 & 3 & \\
\hline & III & 6 & 3 & 3 & \\
\hline & IV & 12 & 5 & 7 & \\
\hline & $\mathrm{V}$ & 14 & 8 & 6 & \\
\hline & VI & 14 & 8 & 6 & \\
\hline & VII & $16^{59}$ & 13 & 3 & \\
\hline & VIII & 9 & 5 & 4 & \\
\hline & IX & 16 & 9 & 7 & \\
\hline & $\mathrm{X}$ & 10 & 7 & 3 & \\
\hline & $\mathrm{XI}$ & 10 & 5 & 4 & 1 \\
\hline & XII & 17 & 8 & 9 & \\
\hline Ukupno 1606. & I-XII & 143 & 84 & 68 & 1 \\
\hline \multirow[t]{12}{*}{1607.} & $\mathrm{I}$ & 30 & 18 & 12 & \\
\hline & II & 20 & 13 & 7 & \\
\hline & III & 20 & 7 & 13 & \\
\hline & IV & 25 & 14 & 11 & \\
\hline & $\mathrm{V}$ & 19 & 13 & 6 & \\
\hline & VI & 6 & 1 & 5 & \\
\hline & VII & 8 & 4 & 4 & \\
\hline & VIII & 7 & 2 & 5 & \\
\hline & IX & 10 & 3 & 7 & \\
\hline & $\mathrm{X}$ & 10 & 6 & 4 & \\
\hline & $\mathrm{XI}$ & 17 & 16 & 1 & \\
\hline & $\mathrm{XII}^{60}$ & 26 & 19 & 7 & \\
\hline Ukupno 1607. & I-XII & 198 & 116 & 82 & - \\
\hline \multirow[t]{7}{*}{1608.} & $\mathrm{I}$ & 38 & 12 & 23 & 3 \\
\hline & II & 29 & 18 & 11 & \\
\hline & III & 33 & 10 & 23 & \\
\hline & IV & 30 & 13 & 17 & \\
\hline & $\mathrm{V}$ & 14 & $8^{61}$ & 6 & \\
\hline & VI & 6 & 4 & 2 & \\
\hline & VII & 6 & 4 & 2 & \\
\hline
\end{tabular}

58 Tri osobe upisane na jedan upis - Luka Kužinović i još dva druga koji su obješeni. Posebno je upisan obješeni Ghega Albanac.

$59 \quad$ Na jedan upis šest osuđenika (giusticiati).

60 Ima 27 upisa, ali je jedan prekrižen.

${ }^{61} \mathrm{Na}$ jedan upis zapisana su četiri poginula vojnika. 


\begin{tabular}{|c|c|c|c|c|c|}
\hline & VIII & 9 & 7 & 2 & \\
\hline & IX & 7 & 4 & 3 & \\
\hline & $\mathrm{X}$ & 6 & 3 & 3 & \\
\hline & $\mathrm{XI}$ & 13 & 7 & 6 & \\
\hline & XII & 13 & 8 & 5 & \\
\hline Ukupno 1608. & I-XII & 204 & 98 & 103 & 3 \\
\hline \multirow[t]{12}{*}{1609.} & $\mathrm{I}$ & 5 & 3 & 2 & \\
\hline & II & 6 & 2 & 4 & \\
\hline & III & 14 & 10 & 4 & \\
\hline & IV & 13 & 6 & 7 & \\
\hline & $\mathrm{V}$ & 7 & 3 & 4 & \\
\hline & VI & 11 & 7 & 4 & \\
\hline & VII & 5 & 4 & 1 & \\
\hline & VIII & 17 & 11 & 6 & \\
\hline & IX & 20 & 13 & 7 & \\
\hline & $\mathrm{X}$ & 3 & 2 & 1 & \\
\hline & $\mathrm{XI}$ & 10 & 5 & 5 & \\
\hline & XII & 12 & 5 & 7 & \\
\hline Ukupno 1609. & I-XII & 123 & 71 & 52 & - \\
\hline \multirow[t]{12}{*}{1610.} & $\mathrm{I}$ & 7 & 4 & 3 & \\
\hline & II & $15^{62}$ & 10 & 5 & \\
\hline & III & 10 & 4 & 6 & \\
\hline & IV & 13 & 7 & 6 & \\
\hline & $\mathrm{V}$ & 8 & 4 & 4 & \\
\hline & VI & 9 & 5 & 4 & \\
\hline & VII & 8 & 4 & 4 & \\
\hline & VIII & 4 & 4 & - & \\
\hline & IX & 16 & 9 & 7 & \\
\hline & $\mathrm{X}$ & 14 & 13 & 1 & \\
\hline & $\mathrm{XI}$ & 11 & 6 & 5 & \\
\hline & XII & 10 & 8 & 2 & \\
\hline Ukupno 1610. & I-XII & 125 & 78 & 47 & - \\
\hline \multirow[t]{9}{*}{1611.} & $\mathrm{I}$ & 15 & 9 & 6 & \\
\hline & II & 2 & 1 & 1 & \\
\hline & III & 5 & 1 & 4 & \\
\hline & IV & 5 & 3 & 2 & \\
\hline & $\mathrm{V}$ & 11 & 9 & 2 & \\
\hline & VI & 5 & 4 & 1 & \\
\hline & VII & 12 & 5 & 7 & \\
\hline & VIII & 8 & 8 & - & \\
\hline & IX & 5 & 1 & 4 & \\
\hline
\end{tabular}

62 Dvije osobe upisane na jedan upis. 


\begin{tabular}{|c|c|c|c|c|c|}
\hline & $\mathrm{X}$ & 10 & 6 & 4 & \\
\hline & $\mathrm{XI}$ & 4 & 1 & 3 & \\
\hline & XII & 8 & 4 & 4 & \\
\hline Ukupno 1611. & I-XII & 90 & 52 & 38 & - \\
\hline \multirow[t]{12}{*}{1612.} & $\mathrm{I}$ & 11 & 4 & 7 & \\
\hline & II & 9 & 4 & 5 & \\
\hline & III & 6 & 5 & 1 & \\
\hline & IV & 6 & 2 & 4 & \\
\hline & $\mathrm{V}$ & 8 & 3 & 5 & \\
\hline & VI & 8 & 4 & 4 & \\
\hline & VII & 7 & 6 & 1 & \\
\hline & VIII & 16 & 10 & 6 & \\
\hline & IX & 17 & 10 & 6 & 1 \\
\hline & $\mathrm{X}$ & 15 & 9 & 6 & \\
\hline & $\mathrm{XI}$ & 17 & 13 & 4 & \\
\hline & XII & 11 & 9 & 2 & \\
\hline Ukupno 1612. & I-XII & 131 & 79 & 51 & 1 \\
\hline \multirow[t]{12}{*}{1613.} & $\mathrm{I}$ & $33^{63}$ & 27 & 6 & \\
\hline & II & 5 & 2 & 3 & \\
\hline & III & 8 & 2 & 6 & \\
\hline & IV & 9 & 6 & 3 & \\
\hline & $\mathrm{V}$ & 10 & 7 & 3 & \\
\hline & VI & 14 & 8 & 6 & \\
\hline & VII & $10+1^{64}$ & $7+1$ & 3 & \\
\hline & VIII & 15 & 8 & 7 & \\
\hline & IX & 14 & 4 & 10 & \\
\hline & $\mathrm{X}$ & 8 & 5 & 3 & \\
\hline & $\mathrm{XI}$ & $6+1^{65}$ & $3+1$ & 3 & \\
\hline & XII & 9 & 5 & 4 & \\
\hline Ukupno 1613. & I-XII & 143 & 86 & 57 & - \\
\hline \multirow[t]{9}{*}{1614.} & I & 18 & 7 & 11 & \\
\hline & II & 11 & 6 & 5 & \\
\hline & III & 6 & 5 & 1 & \\
\hline & IV & 8 & 3 & 5 & \\
\hline & $\mathrm{V}$ & 14 & 5 & 9 & \\
\hline & VI & 12 & 6 & 6 & \\
\hline & VII & 8 & 3 & 5 & \\
\hline & VIII & 18 & 7 & 11 & \\
\hline & IX & 11 & 5 & 6 & \\
\hline
\end{tabular}

63 Tri ubijena u Grusima od Turaka upisana na jedan upis.

${ }^{64}$ Jedan naknadni upis u kolovozu.

65 Jedna smrt upisana u prosincu naknadno. 


\begin{tabular}{|c|c|c|c|c|c|}
\hline & $\mathrm{X}$ & 12 & 6 & 6 & \\
\hline & $\mathrm{XI}$ & 28 & 14 & 14 & \\
\hline & XII & 17 & 7 & 10 & \\
\hline Ukupno 1614. & I-XII & 163 & 74 & 89 & - \\
\hline \multirow[t]{12}{*}{1615.} & $\mathrm{I}$ & 14 & 5 & 9 & \\
\hline & II & 8 & 3 & 5 & \\
\hline & III & 9 & 4 & 5 & \\
\hline & IV & 12 & 8 & 4 & \\
\hline & $\mathrm{V}$ & 10 & 4 & 6 & \\
\hline & $\mathrm{VI}$ & $7^{66}$ & 4 & 3 & \\
\hline & VII & 14 & 8 & 6 & \\
\hline & VIII & 35 & 20 & 15 & \\
\hline & IX & 20 & 12 & 8 & \\
\hline & $\mathrm{X}$ & 11 & 6 & 5 & \\
\hline & $\mathrm{XI}$ & 16 & 8 & 8 & \\
\hline & XII & 12 & 5 & 7 & \\
\hline Ukupno 1615. & I-XII & 168 & 87 & 81 & - \\
\hline \multirow[t]{12}{*}{1616.} & $\mathrm{I}$ & 10 & 4 & 6 & \\
\hline & II & 12 & 5 & 7 & \\
\hline & III & 10 & 8 & 2 & \\
\hline & IV & 15 & 8 & 7 & \\
\hline & $\mathrm{V}$ & 17 & 10 & 7 & \\
\hline & VI & 16 & 6 & 10 & \\
\hline & VII & 16 & 8 & 8 & \\
\hline & VIII & $28^{67}$ & 16 & 12 & \\
\hline & IX & 12 & 5 & 7 & \\
\hline & $\mathrm{X}$ & $9+1$ & 6 & $3+1^{68}$ & \\
\hline & $\mathrm{XI}$ & 25 & 10 & 15 & \\
\hline & XII & 8 & 3 & 5 & \\
\hline Ukupno 1616. & I-XII & 179 & 89 & 90 & - \\
\hline \multirow[t]{6}{*}{1617.} & $\mathrm{I}$ & 5 & 3 & 2 & \\
\hline & II & 9 & 5 & 4 & \\
\hline & III & 9 & 7 & 2 & \\
\hline & IV & 10 & 7 & 3 & \\
\hline & $\mathrm{V}$ & 8 & 5 & 3 & \\
\hline & VI & 16 & 11 & 5 & \\
\hline Ukupno 1617. & I-VI & 57 & 38 & 19 & - \\
\hline UKUPNO & $\begin{array}{c}\text { od ožujka1597. } \\
\text { do kraja lipnja } \\
1617 .\end{array}$ & 3162 & 1795 & 1360 & 7 \\
\hline
\end{tabular}

66 Ima osam upisa, ali je jedan precrtan.

67 Ima 28 upisa i jedan je prekrižen.

68 Jedna smrt iz listopada upisana je u studenom. 


\section{Uzroci smrti}

Zbog nedostatnih podataka u upisima, posebno onih o uzroku smrti, tek na osnovi drugih izvora te usporedbe zapisa iz matičnih knjiga drugih mjesta zadarskog područja može se utvrditi da je u Zadru u neko vrijeme vladala neka zarazna bolest. Ne možemo, kao u manjim mjestima, procijeniti broj umrlih u nekom kratkom razdoblju po kućanstvima, jer se u većem gradu ne može lako utvrditi identitet neke osobe, a upis nam ne govori da je riječ o istoj obitelji. Po prezimenima se ne možemo ravnati jer u većem gradu isto prezime može biti raspoređeno na puno veći broj obitelji nego u manjem selu, a i veća je mogućnost da se osoba koristi s više prezimena (nadimak, patronimik ili matronimik i obiteljsko prezime). Tek kod nekoliko slučajeva može se odrediti da je nekoliko osoba iz iste obitelji umrlo u roku od par dana, ali ne i uzrok smrti (npr. iz obitelji Grge Piccolla).

Župnik je upisivao samo (možda ne i sve) osobe umrle nasilnom smrću, ubijene i osuđene na vješala, dok je jednoj osobi upisano da je bila osuđena na veslanje, tj. na galiju, ali joj nije zapisan pravi uzrok smrti.

TABLICA 2. Nasilne smrti (obješeni i ubijeni) (Izvor: HR-AZDN, Zadar, MKU 1597.-1917.)

\begin{tabular}{|l|l|l|}
\hline $\begin{array}{l}\text { Datum upisa } \\
\text { (pogreba) }\end{array}$ & Ime i prezime i način smrti & Mjesto pokopa \\
\hline 24.4.1597. & Morlak & Sv. Ivan \\
\hline 15.10.1597. & Ivan Francesko ili Francuz (Zuanne Francesce) - bio je obješen & Sv. Frane \\
\hline 22.9.1598. & Jakov iz Istre - obješen & Sv. Frane \\
\hline 19.1.1600. & $\begin{array}{l}\text { Vid Jelačić, konjanik u prošlom ratu, vjerojatno Ciparskom ratu, }{ }^{69} \\
\text { zadnje vrijeme služio kod kolonela Canallea - ubijen od Turaka }\end{array}$ & Sv. Mihovil \\
\hline 5.10.1601. & Martin Lučić iz Nina - ubijen & Sv. Dimitrije \\
\hline 27.10.1602. & Grgo i Mate Margetić iz Bibinja te njihov nećak Pavle - pogubljeni & $\begin{array}{l}\text { Sv. Ivan x } 2 \\
\text { Sv. Marija }\end{array}$ \\
\hline 8.3.1603. & Jedan Grk koji je ubijen & Sv. Ilija \\
\hline 8.3.1603. & Zuanne Cipuracchi - završio u kanalu & - \\
\hline 12.7.1603. & Nikola Stoičić iz Grusi ubijen od Turaka & Sv. Ivan \\
\hline 23. 8.1603. & Šimun Matešić iz Ugljana - pogubljen & $\begin{array}{l}\text { Pokopan na tom } \\
\text { otoku }\end{array}$ \\
\hline 27.9.1603. & Domenigo sopramasser Šibenčan i još pet drugova - obješeni & $\begin{array}{l}\text { Pokopani u } \\
\text { Sv. Ivanu i Sv. } \\
\text { Silvestru }\end{array}$ \\
\hline 8.6.1604. & Ivana Puljanka (Puglise) - ubijena od nekog stradiota & Sv. Katarina \\
\hline 31.7.1604. & Miho Pušić iz Kožina - ubijen & Sv. Silvestar \\
\hline 4.9 .1604$. & $\begin{array}{l}\text { Ante Ćivković (Chiucovich) Šibenčanin - obješen (fu appicato alla } \\
\text { lantiena) }\end{array}$ & Sv. Krševan \\
\hline
\end{tabular}

69 U matici piše u prošlom ratu. 


\begin{tabular}{|l|l|l|}
\hline 7.9.1604. & Cvitko Operčić iz Hrašćana - ubijen od ubojica & Sv. Ilija \\
\hline 1.10.1604. & Zuane Papado proto - ubijen & Sv. Ilija \\
\hline 3.10.1604. & Kapetan Nikola Pačić - ubijen u borbi & Sv. Dominik \\
\hline 12.7.1605. & Nikola od Marka Aurorija - ubijen od uskoka & Sv. Ilija \\
\hline 3.10.1605. & Luka Kužinović s dva druga - obješeni (appicati alla lantiena) & $\begin{array}{l}\text { Sv. Krševan (sva } \\
\text { trojica) }\end{array}$ \\
\hline 3.10.1605. & S ovim gornjima je bio obješen i Ghega Albaneze & Sv. Frane \\
\hline 10.2.1606. & M. Mattio Scrisa, zlatar - ubijen & Sv. Roko \\
\hline 17.5.1606. & Tomaso Bigliacovich - ubijen & Sv. Ivan \\
\hline 22.5.1606. & Dominigo Romanizza Napolitano -ubijen & - \\
\hline 26.6.1606. & Pavle Kosovac iz Malpage - ubijen & Sv. Silvestar \\
\hline 26.7.1606. & $\begin{array}{l}\text { Desidero d'Ascoli logotelente et Lorenzo, Cornelio, Orattio, } \\
\text { Mattio, Stefano et Giovanni - bili su osuđeni }\end{array}$ & Sv. Frane x 7 \\
\hline 31.3.1607. & Polonia Diuçichia (Dujčić) - ubio je suprug & Sv. Stjepan \\
\hline 7.5.1608. & $\begin{array}{l}\text { Ubijeni od Turaka: Giovanni Gardon del capo Rondachi; } \\
\text { Giovanne Grimani, Biaso Grubaçich (Blaž Grubačić) i Pietro, sin } \\
\text { kapetana Nikole Rondachia }\end{array}$ & Sv. Stjepan x 4 \\
\hline 28.11.1609. & Vid Meštrović iz Bokanjca - ubijen & Sv. Dimitrije \\
\hline 20.3.1610. & Pietro Checich (Kekić, Čekić), stradiot ubijen od Turaka & Sv. Ilija \\
\hline 31.10.1611. & $\begin{array}{l}\text { Grigorio Vuletta da Zara Vechia (Grgo Vuleta iz Biograda) - } \\
\text { ubijen }\end{array}$ & Sv. Katarina \\
\hline 2.1.1613. & $\begin{array}{l}\text { Tri vojnika iz Grusa ubijena od Turaka: Jurašin Zoić, Andrija } \\
\text { Račić, Filip Marcolić }\end{array}$ & Sv. Frane x 3 \\
\hline 17.11.1616. & Matija iz Trogira, ubio ju je suprug & Sv. Krševan \\
\hline
\end{tabular}

\section{MJESTA UKOPA}

Umrle osobe pokapale su se unutar crkava, u ovom razdoblju nema slučajeva pokopa u grobljima oko crkava. U nekim slučajevima bilo je naznačeno i u kojoj grobnici unutar crkava je osoba pokopana jer su pojedine bratovštine imale svoju grobnicu u crkvi: npr. grobnice sv. Stjepana i Sv. Sakramenta u Katedrali. Ukupno su bile u upotrebi 22 zadarske crkve, od čega se ne može katkad po upisima točno odrediti o kojoj crkvi je riječ, odnosno je li mjesto pokopa bilo raspoređeno po ostalim crkvama sličnog imena npr. Sv. Marija de Pusterla, Sv. Marija, Sv. Marija de Borgo (Varoška), samo se katkad Sv. Marija označava kao Sv. Marija Stara ili Sv. Marija Manastirska i sl. ${ }^{70}$ Najveći

70 R. JELIĆ, Stanovništvo Zadra u drugoj polovici XVI i početkom XVII stoljeća gledano kroz matice vjenčanih, 351 - 353; Roman Jelić u svojoj knjizi o zadarskim maticama vjenčanih iz razdoblja od 1576. do 1613. spominje da je u maticu upisana ukupno 31 crkva ili kapelica, od čega više crkava s imenom sv. Marije. U matici vjenčanih spominje se da su u tom vremenu u upotrebi u Zadru bile 
broj pokopa bio je u crkvi sv. Frane (638 - 20,18 \%), koja je imala grobnicu za pokop vojnika, a veći broj pokopa obavljen je u crkvama sv. Dominika (311 $-9,84 \%)$, sv. Silvestra, gdje su se najviše pokapali Varošani $(255-8,08 \%)$, te katedrali sv. Stošije (211 - 6,99 \%). Značajan broj pokopa je bio i u crkvama koje su porušene i čiji točan položaj danas nije poznat. Kapela sv. Šime ne odnosi se na današnju crkvu sv. Šime, nego na kapelicu na položaju oko Sv. Marije Svećeničke (Velike) koja je 1570. porušena za izgradnju bedema, ${ }^{71}$ a današnja crkva sv. Šimuna u to je vrijeme nosila naziv crkva sv. Stjepana.

Zbog započetih radova na izgradnji bedema (Fortea) 1567. godine, slika Gospe od Varoša u svečanoj je procesiji prenesena u crkvu sv. Stjepana (danas sv. Šimuna). ${ }^{72}$ Sliku su nosili stradioti Matio i Zorzi (Jure), otac i sin, koji su umrli 14. travnja 1603. godine.

U crkvi sv. Frane vjerojatno je bila grobnica za vojnike, jer je više od trećine vojnika i časnika pokopano baš u ovoj crkvi.

Članovi bratovština sv. Silvestra i bratovština zadarskih Varošana aktivno su sudjelovali prilikom izvršavanja smrtnih presuda, pratili osuđenike na vješala i dostojno ih pokapali, sudjelovali u ukopu siromaha i bolesnih od zaraznih bolesti, npr. u vrijeme epidemije kuge. ${ }^{73}$

TABLICA 3. Prosjaci (Izvor: HR-AZDN, Zadar, MKU 1597.-1917.)

\begin{tabular}{|l|l|l|}
\hline $\begin{array}{l}\text { Datum upisa } \\
\text { (pogreba) }\end{array}$ & Ime i prezime & Mjesto pokopa \\
\hline 17.2.1598. & Jedna uboga (povera) Šibenčanka & Sv. Silvestar \\
\hline 29.10.1600. & Todora siromašna & Sv. Stjepan \\
\hline 18.12.1600. & Margarita, povera da isula (siromašica s otoka) & $\begin{array}{l}\text { Sv. Stjepan } \\
\text { iz samilosti } \\
\text { (carita) }\end{array}$ \\
\hline
\end{tabular}

sljedeće crkve: Sv. Ivan Krstitelj; Sv. Dominik; Sv. Frane; Sv. Krševan; Sv. Marija redovnička; Sv. Kata; Sv. Nikola; Sv. Dimitrij; Sv. Mihovil; Sv. Ivan kovački (koji se još naziva Sv. Ivan od Pusterle ili Sv. Dominika - Sv. Nediljica); Sv. Petar na malom trgu koji se još nazivao Sv. Marija od Navištenja, Sv. Marija na malom trgu (S. Pietro della piazza piccolo; S. Maria Annunziata; S. Maria de platea parva; S. Maria de piazza parva; S. Maria della piazzola); Sv. Andrija; Sv. Šime; Sv. Roko; Sv. Marija svećenička; Sv. Stjepan ili Gospe od Varoša (Madona del Borgo); Sv. Silvestar; Sv. Spas; Četrdeset mučenika; Sv. Vid; Sv. Donat; Gospa od Kaštela ili Gospa od novih bunara; Sv. Jure; Sv. Stošija katedrala; Sv. Lovre; Sv. Bernardin; Gospe od dobrog veselja (dobre radosti - Madonna de buon gaudio); Sv. Ilija; Kapela u kneževoj palači; Kapela u Tvrđavi (kamerlengova kapela); Kapela u bolnici za kažnjenike; Kapela u hospitalu sv. Marka; Kapela u hospitalu sv. Jakova.

71 Nada Klaić, Ivo Petricioli, Zadar u srednjem vijeku, Zadar, 1976.

72 Zdenko Dundović, Bratovština zadarskih Varošana, Zadar, 2020., 87.

73 Z. Dundović, Bratovština zadarskih Varošana, Poglavlje: Karitativno-društvena djelatnost bratovštine, njezin temeljni cilj, $54-61$. 
Dio osoba umro je po zadarskim hospitalima. ${ }^{74} \mathrm{U}$ matici se spominju hospitali sv. Donata, sv. Marka, sv. Bernardina, Madona del Borgo i Ospitale della militia di Zara.

TABLICA 4. Umrli po zadarskih hospitalima (Izvor: HR-AZDN, Zadar, MKU 1597.-1917.)

\begin{tabular}{|l|l|l|}
\hline $\begin{array}{l}\text { Datum upisa } \\
\text { (pogreba) }\end{array}$ & Ime i prezime ili Upis & Mjesto pokopa \\
\hline 16. 1. 1597. & Madalena iz hospitala sv. Donata & Sv. Donat \\
\hline 14.1.1599. & Šime Ružić, težak, umro u hospitalu sv. Donata & Sv. Donat \\
\hline 29.11.1599. & Anzola, žena M. Valeria spidaliera iz hospitala sv. Marka & Sv. Frane \\
\hline 7.11.1605. & Anastasia de Dobra iz hospitala Sv. Bernardina & Sv. Katarina \\
\hline 26.4.1607. & Signor Valerio da Pisaro, prior del ospitale della militia di Zara & Sv. Frane \\
\hline 12.5.1612. & Cattarina Ambrozića, hospital Madona del Borgo & Sv. Stjepan \\
\hline
\end{tabular}

TABLICA 5. Mjesta pokopa (Izvor: HR-AZDN, Zadar, MKU 1597.-1917.)

\begin{tabular}{|l|c|c|}
\hline Mjesto pokopa & $\begin{array}{l}\text { Broj ukopa } \\
\text { u razdoblju } \\
\text { pisanja matice }\end{array}$ & Postotak \\
\hline Sv. Dimitrije & \\
\hline Sv. Dominik & 88 & $2,78 \%$ \\
\hline Sv. Donat & 311 & $9,84 \%$ \\
\hline Sv. Frane & 98 & $3,1 \%$ \\
\hline Sv. Ilija $^{76}$ & 638 & $20,18 \%$ \\
\hline Sv. Ivan $^{77}$ & 170 & $5,38 \%$ \\
\hline Sv. Katarina $^{78}$ & 174 & $5,5 \%$ \\
\hline Sv. Krševan & 142 & $4,49 \%$ \\
\hline
\end{tabular}

74 R. Jelić, Stanovništvo Zadra 1608. godine; R. Jelić, Zdravstvo u Zadru i njegovu području. Jelić nabraja veliki broj hospitala u zadarskoj prošlosti.

75 N. Klaić, I. Petricioli, Zadar u srednjem vijeku, 284; R. Jelić, Stanovništvo Zadra u drugoj polovici XVI i početkom XVII stoljeća gledano kroz matice vjenčanih, 352: Crkva i ženski samostan sv. Dimitrija nalazio se uz bedeme na današnjoj Poljani Natka Nodila. U crkvi je bila grobnica krbavskih knezova Kurjakovića. C. F. BianchI, Zara Cristiana, I, Zadar, 1877., 435 - 442.

76 R. JeLIĆ, Stanovnišstvo Zadra u drugoj polovici XVI i početkom XVII stoljeća gledano kroz matice vjenčanih, 353: „Crkva sv. Ilije ustupljena je Grcima nastanjenima u Zadru.“; C. F. BiANCHI, Zara Cristiana, I, 450 - 453.

77 N. Klaić, I. Petricioli, Zadar u srednjem vijeku, 284; R. Jelić, Stanovništvo Zadra u drugoj polovici XVI i početkom XVII stoljeća gledano kroz matice vjenčanih, 352: Sv. Ivan kovački (koji se još naziva Sv. Ivan od pusterle ili Sv. Dominika - Sv. Nediljica) nalazi se u ulici Stomorice na mjestu nekadašnjeg Folklora; C. F. BIANCHI, Zara Cristiana, I, $414-415$.

78 R. Jelić, Stanovništvo Zadra u drugoj polovici XVI i početkom XVII stoljeća gledano kroz matice vjenčanih, 352; Crkva sv. Katarine nalazila se na mjestu nekadašnje kavane Central u Širokoj ulici; C. F. BIANCHI, Zara Cristiana, I, $442-444$. 


\begin{tabular}{|c|c|c|}
\hline Sv. Marcela ${ }^{79}$ & 50 & $1,58 \%$ \\
\hline Sv. Marija & 317 & $10,02 \%$ \\
\hline Sv. Marija Piaccolla & 39 & $1,23 \%$ \\
\hline Sv. Mihovil & 122 & $3,86 \%$ \\
\hline Sv. Nikola & 103 & $3,26 \%$ \\
\hline Sv. Roko & 66 & $2,09 \%$ \\
\hline Sv. Silvestar ${ }^{80}$ & 255 & $8,06 \%$ \\
\hline Sv. Stjepan ${ }^{81}$ & 120 & $3,79 \%$ \\
\hline Sv. Stošija - Katedrala & 221 & $6,99 \%$ \\
\hline Sv. Šime ${ }^{82}$ & 10 & $0,33 \%$ \\
\hline $\begin{array}{l}\text { Ostalo (Sv. Andrija } 1 ;{ }^{83} \text { Sv. Juraj } 2 ; ;^{84} \text { Sv. Kasijan } 1 \text {; Madona di } \\
\text { Borgo } 2 ; 8^{85} 40 \text { mučenika } 1 ;{ }^{86} \text { nečitljivo - } 1 \text {; mjesta izvan grada } \\
\text { kao što su Sukošan, Ugljan - 2) }\end{array}$ & 9 & $0,28 \%$ \\
\hline Nepoznato (nije upisano mjesto pokopa) & 37 & $1,17 \%$ \\
\hline
\end{tabular}

79 Crkva i samostan bili su u blizini tržnice, pokraj crkve sv. Petra starog i Andrije. Marija Stagličić, Sanja Šтoк, Crkva i samostan sv. Marcele u Zadru, Prilozi povijesti umjetnosti u Dalmaciji, vol. 36, br. 1., Split, 1996., $187-204$.

80 Crkva se nalazila se na kraju današnje Kovačke ulice. N. Klaić, I. Petricioli, Zadar u srednjem vijeku, 284;. R. JeLIĆ, Stanovništvo Zadra u drugoj polovici XVI i početkom XVII stoljeća gledano kroz matice vjenčanih, 351. Jelić u knjizi Stanovništvo Zadra u drugoj polovici XVI i početkom XVII stoljeća gledano kroz matice vjenčanih piše da je ovdje riječ o crkvi sv. Ivana Krstitelja, koja se do 1541. godine nazivala Sv. Silvestar, uz koju je bio samostan trećoredaca glagoljaša. Crkva sv. Silvestra koja se spominje u maticama vjenčanih 1576. - 1613. po Jeliću je bila uz crkvu sv. Krševana. Po Petricioliju tu je riječ o crkvi sv. Tome, a ne sv. Silvestra. N. Klaić, I. Petricioli, Zadar u srednjem vijeku, 284.

81 R. JeLIĆ, Stanovništvo Zadra u drugoj polovici XVI i početkom XVII stoljeća gledano kroz matice vjenčanih, 352, piše da je današnja crkva sv. Šime bila posvećena sv. Stjepanu, čije ime je nosila do 1632. kad je u nju prenesena škrinja sv. Šime. Ivo Petricioli, Škrinja sv. Šimuna u Zadru, Zagreb, 1983. U nju je 1567. godine bila prenesena slika Gospe od Varoša iz porušene crkve u zadarskom predgrađu. Roman Jelić piše da se crkva sv. Stjepana zvala i Madona de Borgo zbog slike; C. F. BIANCHI, Zara Cristiana, I, 334 - 356.

82 Kapele sv. Roka i sv. Šime bile su na mjestu nekadašnje crkve sv. Marije Velike na tržnici, koja je dijelom bila porušena 1570. radi gradnje bedema. R. JeLIĆ, Stanovništvo Zadra u drugoj polovici XVI i početkom XVII stoljeća gledano kroz matice vjenčanih, 352; C. F. BIANCHI, Zara Cristiana, I, 390 - 397.

83 Crkvica sv. Andrije spojena je s crkvom sv. Petra starog, a nalazi se na zadarskoj tržnici. R. Jelić, Stanovništvo Zadra u drugoj polovici XVI i početkom XVII stoljeća gledano kroz matice vjenčanih, 352; C. F. BIANCHI, Zara Cristiana, I, 448.

84 N. Klaić, I. Petricioli, Zadar u srednjem vijeku, 284; Crkvica se nalazila kod crkve sv. Frane, prema obali.

85 Iako Jelić tvrdi da je riječ o crkvi sv. Stjepana koju su zvali Madona de Borgo radi slike koja je u nju prebačena iz srušenog Varoša, ovdje je crkva Madona de Borgo izdvojena kao što je i upisivana u matične knjige. U zadarskom Varošu postojala je još jedna crkva sv. Marije - Sv. Marija de Bon Gaudio, koju su također mogli nazivati Madona de Borgo. N. Klaić, I. Petricioli, Zadar u srednjem vijeku, 284.

86 Crkva se nalazila u Širokoj ulici, na uglu preko puta Arheološkog muzeja i kavane Forum. N. KLAIĆ, I. Petricioli, Zadar u srednjem vijeku, 284. 


\section{Broj ukopa po zadarskim crkvama}

\section{$25,00 \%$}

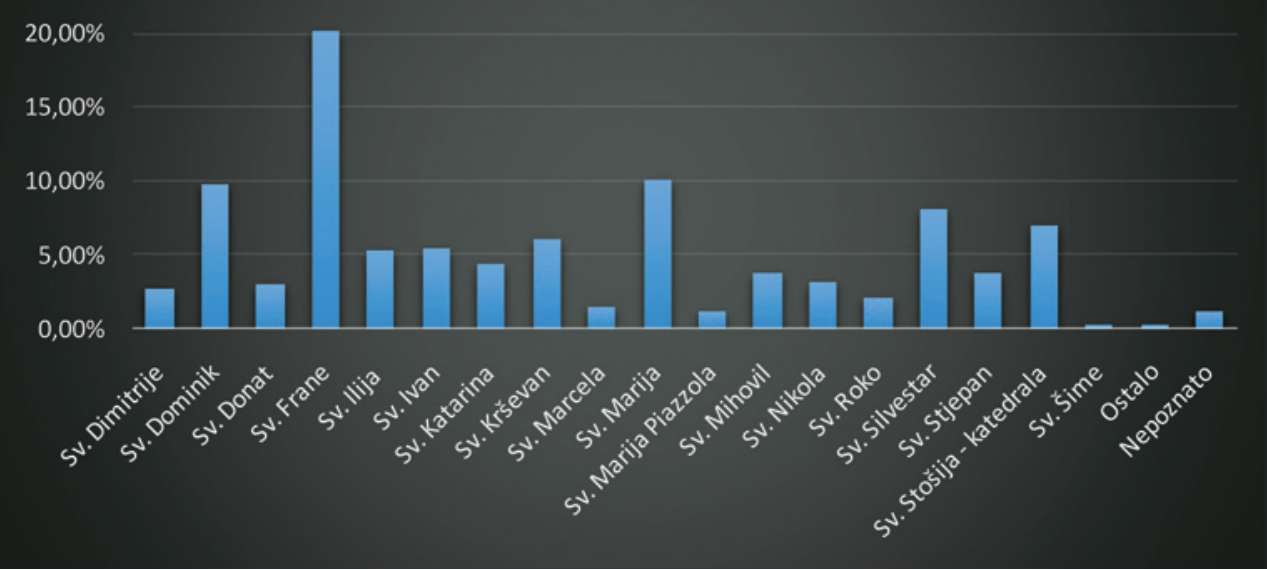

GRAFIKON 1. Broj ukopa po zadarskim crkvama (Izvor: HR-AZDN, Zadar, MKU 1597.-1917.)

Najveći broj pokopa bio je u crkvi sv. Frane (20,18 \%), nešto manje u Sv. Dominiku (9,84 \%), Sv. Mariji (10,02 \%), Sv. Silvestru (8,06 \%), katedrali sv. Stošije (6,99 \%) i Sv. Krševanu (6,07 \%). Ostali ukopi raspoređeni su po manjim crkvama.

\section{STRUKTURA ZADARSKOG STANOVNIŠTVA}

Po popisima stanovništva 1527. i 1608. najveći broj Zadrana činili su pučani, a od zanimanja težaci, obrtnici. Matične knjige nisu pokazatelj točne strukture kompletnog stanovništva nekog mjesta, a statistički se može prikazati samo broj upisanih osoba u maticu.

U maticama nisu strogo određene pojedine kategorije stanovnika kao što je to slučaj u popisima stanovnika. Neki su u isto vrijeme pripadnici klera i članovi obitelji obrtnika, neki su u isto vrijeme obrtnici i članovi vojne posade, neki su u isto vrijeme plemići i pripadnici vojske itd. 


\section{Plemstvo}

Plemstvo je obrađeno samo na temelju prezimena jer u većini slučajeva titula nije upisana u matice. Katkad su upisivani sa skraćenim titulama ser (sior), donna, madonna, El clarissimo sior, El magnifico sior, siora i sl. ${ }^{87}$

Većina plemića već je upisana u evidencije kao svećenici i redovnice, upravitelji (civilne vlasti i vojne vlasti), visoki časnici, liječnici (dottore Fumati), trgovci, a u ovom razdoblju nalazimo pripadnike sljedećih plemićkih zadarskih obitelji: Bartulacich; Begna alias Barbarella ili Barbarelli; Begna alias Giaschich (Jašić); Begna alias Grisogono; Begna detto Scamich; Begna ili Benjačić; Calzina; Carnaruti ili Carnaruto ili Charnaruti; Cedolini ili Cedulin; Civallelli; Clococeo; da Possedaria; de Martinis; Fanfogna; Fera ili Ferra; Foscarini; Fumatti; Grisigono alias Bartulacich; Grisigono al(ia)s Borssich; Grisigono detto Bartolazzi; Grisigono detto Burich; Ligniceo; Nassi; Pechiari; Rosa alias Spagnoletti; Rosa; Sagic; Soppe; Spingaroli ili Spingarello; Thetrico ili Tetrico ili Detrico; Venier.

Manji broj je pripadnika plemićkih obitelji koje nisu iz Zadra: Galleli, d'Ascou, nobili da Arbe, Magco sior Cristoforo Nemira nobil d' Arbe; Cipico nobile Spalattin; Lipamano, Girandini; Gerardini.

Neke su osobe upisane samo imenom i titulom bez da se može odrediti o kojem je plemiću riječ. U maticama je upisan Conte Carlo (1599.), a iz drugog upisa možemo pretpostaviti da je riječ o conteu Carlu Sentinelliju, kapetanu (nekoliko puta se pojavljuje u upisima 1599. godine).

Umrli se pokapaju uglavnom u crkvama sv. Frane, sv. Marije, sv. Dominika, a nešto manje u ostalim gradskim crkvama.

\section{Obrtnici, pomorska i uslužna zanimanja}

Nakon Ciparskog rata u gradu je opao broj obrtnika, koji su nastradali prilikom ratnih operacija ili koji su tada bili angažirani na Zadarskoj galiji nestaloj u Lepantskoj bitci. ${ }^{88}$ Neko vrijeme nije bilo ni sirovine npr. vune, koja

${ }^{87}$ Popis je napravljen usporedbom sa sljedećim knjigama i člancima: R. JELIĆ, Stanovništvo Zadra u drugoj polovici XVI i početkom XVII stoljeća gledano kroz matice vjenčanih, 349 - 509; R. JEliĆ, Stanovništvo Zadra 1608. godine, Zadar, 1985., 108; D. MADunić, Mjera grada: Zadarski popis stanovništva 1527. godine, 23 - 62; Serđo DokozA, Mladen Andreis, Zadarsko plemstvo u srednjem vijeku, Zadar, 2020.; Miroslav Granić, Denis Martinović, Plamstvo kraljevine Dalmacije 1814. - 1918., Zadar, 2018.

88 Ante Usmiani, Sudbina zadarske galije predviđene za bitku kod Lepanta, Lepantska bitka - udio hrvatskih pomoraca u lepantskoj bitki 1571. godine, Zadar, 1974., 105 - 118. 
je pristizala iz Bosne. ${ }^{89}$ Dio obrtnika doselio je s područja Mletaka, a rijetki s nekih drugih područja poput Južne Italije, Jonskih otoka, Austrije i Njemačke. ${ }^{90}$ Svaka obrtnička skupina imala je vlastitu bratovštinu. ${ }^{91}$ Zidari, kovači i stolari imali su svog nadglednika (protu) koji je najviše bio zauzet poslovima u korist države, vezano uz vojsku, organizaciju javnih radova, posebno gradnjom javnih građevina. ${ }^{92} \mathrm{U}$ gradu i po otocima bio je poneki kalafat koji je popravljao brodove, ali brodogradilište nije postojalo te su se brodovi kupovali izvan Zadra. ${ }^{93}$ Mnoge zadarske plemićke i građanske obitelji posjedovale su manje brodove, bracere i gripone za prijevoz do otoka. ${ }^{94}$ Krajem 16. stoljeća ovo je područje imalo više većih brodova za prijevoz stoke i ostale robe nego je bilo potrebno. ${ }^{95}$ Početkom 17. stoljeća u Zadru djeluje petnaestak trgovaca na veliko i malo, a smirivanjem situacije na mletačko-turskoj granici povećava se i broj trgovaca. ${ }^{96}$

Godine $1608 .{ }^{97}$ na popisu nalazimo upisano osam ljekarnika. ${ }^{98}$ Osim otvorenih trgovina, u gradu su se održavali i sajmovi poput onoga na Dan sv. Krševana. ${ }^{99}$ Trgovina s turskim trgovcima odvijala se na cestama ili ispod gradskih bedema, a prodavalo se uglavnom žito, stoka te sirovina poput drva, vune ili sirovog željeza. ${ }^{100}$ Iz Zadra se izvozila stoka i žito, male količine vina, smokava, slanih maslina i soljenih srdela. ${ }^{101}$ Novak-SAmbrailo, Plemići, građani i pučani u Zadru (XV-XVII st.), Radovi Zavoda za povijesne znanosti HAZU u Zadru, 19, Zadar, 1972., 184.

90 T. Raukar, I. Petricioli, F. Švelec, Š. Peričić, Zadar pod mletačkom upravom, 384.

91 Vladislav Cvitanović, Bratovštine grada Zadra, Zbornik Zadar, Zagreb, 1964., 457 - 470.

92 T. Raukar, I. Petricioli, F. Švelec, Š. Peričić, Zadar pod mletačkom upravom, 385; Zdenko Dundović, Bratovština kovača u Zadru i njezina matrikula iz 15. stoljeća, Povijesni prilozi, 38, Zagreb, 2019., 56, 229 - 160.

93 T. Raukar, I. Petricioli, F. Švelec, Š. Peričić, Zadarpod mletačkom upravom, 388.

94 T. Raukar, I. Petricioli, F. Švelec, Š. Peričić, Zadar pod mletačkom upravom, 390.

95 Nikola Čola K, Naše ribarstvo do pada Mletačke Republike, Pomorski zbornik, I i II, Zadar, 1962.; T. Raukar, I. Petricioli, F. Švelec, Š. Peričić, Zadar pod mletačkom upravom, 390.

96 T. Raukar, I. Petricioli, F. Švelec, Š. Peričić, Zadar pod mletačkom upravom, 391.

97 R. Jelić, Stanovništvo Zadra 1608. godine, 104. Na Popisu 1608. većem broju obrtnika (66) nije upisano zanimanje. Slično je s ostalim zanimanjima.

98 R. Jelić, Stanovnišstvo Zadra 1608. godine, 109; T. RaU Kar, I. Petricioli, F. Švelec, Š. Peričić, Zadar pod mletačkom upravom, 404; Roman Jelić, Zdravstvo u Zadru i njegovu području, Zadar, 1978., 256. Jelić spominje najstariju zadarsku ljekarnu koju je osnovao Ivan Bianchi iz Bergama 1561. godine, a nosila je naziv $K$ andelu, koja je još uvijek na istom mjestu na uglu Varoške i Borellijeve ulice.

99 T. Raukar, I. Petricioli, F. Švelec, Š. Peričić, Zadar pod mletačkom upravom, 393. Krajem 17. stoljeća otvara se još jedan sajam, onaj sv. Šimuna koji je trajao od 2. do 9. lipnja svake godine.

100 T. Raukar, I. Petricioli, F. Švelec, Š. Peričić, Zadar pod mletačkom upravom, 394.

101 T. Raukar, I. Petricioli, F. Švelec, Š. Peričić, Zadar pod mletačkom upravom, 398. 
Osim brojnih obrtničkih zanimanja, na Popisu 1608. godine pojavljuju se ribari, kojih je bilo 28, ${ }^{102}$ a okupljali su se oko bratovštine sv. Andrije, ${ }^{103}$ zatim mornari (11) i težaci (59). Na popisu nije upisan ni jedan mlinar, dok u matici imamo zabilježena četiri. ${ }^{104}$

Velik broj pučana bavio se zemljoradnjom, a to su bili uglavnom žitelji gradskog Varoša, koji su zbog sigurnosti danju obrađivali polja u zadarskoj okolici, a noću se sklanjali u grad. ${ }^{105}$ Oni su imali i određen broj stoke koju su napasali u neposrednoj gradskoj okolici, a kada je postojala opasnost od osmanskih napada, i po gradskim bedemima. ${ }^{106}$ Bili su okupljeni u bratovštini zadarskih Varošana. ${ }^{107}$

Tijekom 16. stoljeća u Zadru se bilježe učitelji i profesori gramatike, a u 17. stoljeću rettori di littere d'umanitta.

Do druge polovice 17. stoljeća u Zadru je egzistirala kaptolska škola, dok se službeni početak djelovanja latinskog Florijeva sjemeništa može datirati u školsku godinu 1669./1670., a mletački prokuratori de supra obznanili su pravilnik o radu sjemeništa u 28 kapitula 25. srpnja 1669. godine. ${ }^{108}$

U crkvama su postojali orguljaši i dirigent, pa je u maticama zabilježen jedan organist (orguljar), dva koralista, a pri vojsci su zabilježeni trubači (4) i bubnjari (2).

O zdravlju i liječenju stanovnika grada i okolice brinuli su se jedan liječnik i jedan kirurg, koje je općina zapošljavala na temelju natječaja i davala im veliku plaću. Svaka bolnica (hospital) imala je barem jednog liječnika koji je u slobodno vrijeme brinuo o zdravlju svih stanovnika. ${ }^{109}$

U ovoj matici umrlih nalazimo ukupno 42 različita obrtnička, pomorska i uslužna zanimanja s 667 pripadnika ili članova njihovih obitelji, 33 pripadnika

102 R. JELIĆ, Stanovništvo Zadra 1608. godine, 108.

103 V. Cvitanović, Bratovštine grada Zadra, 457 - 470; Vladislav Cvitanović, Privilegij pomilovanja bratovštine Gospe od Sniga, Gospe od navještenja i sv. Andrije u Zadru (u 17. st.), Pomorsko zanimanje Ižana, Starine, knj. 5, Zagreb, 1955., 173 - 280.

104 Usporedi broj i zanimanja u ovom razdoblju u Zadru s onima u istarskim matičnim knjigama $u$ članku Slavena Bertoše, Obrti i neka ostala zanimanja u Puli od 17. do 19. stoljeća, Povijesni prilozi, 20, Zagreb, 2001., 21, $121-159$.

105 T. Raukar, I. Petricioli, F. Švelec, Š. Peričić, Zadar pod mletačkom upravom, 380, 400.

106 T. Raukar, I. Petricioli, F. Švelec, Š. Peričić, Zadar pod mletačkom upravom, 380.

107 Zdenko Dundović, Bratovština zadarskih Varošana, Zadar, 2020.

108 Slavko Kovačıć, Katedralne škole u Dalmaciji pod mletačkom vlašću od konca 16. do početka 19. stoljeća prema biskupskim izvještajima Svetoj Stolici, Croatica christiana periodica, br. 27, Zagreb, 1991., 59 - 87; Z. Dundović, Florijevo sjemenište u Zadru - prilog poznavanju njegova otvorenja i djelovanja, Croatica christiana periodica, br. 86, Zagreb, 2020., 87 - 110.

109 T. Raukar, I. Petricioli, F. Švelec, Š. Peričić, Zadar pod mletačkom upravom, 404. 
civilnih vlasti, javnih službenika i članova njihovih obitelji te 143 svećenika, redovnica, klerika i članova njihovih obitelji.

TABLICA 6. Obrtnici, pomorska i uslužna zanimanja (Izvor: HR-AZDN, Zadar, MKU 1597.-1917.)

\begin{tabular}{|c|c|}
\hline Zanimanje & $\begin{array}{l}\text { Broj obrtnika i članova } \\
\text { njihovih obitelji koji su } \\
\text { upisani u MKU }\end{array}$ \\
\hline Stolar (marangun) & 13 \\
\hline Brodograditelj (kalafat) & 8 \\
\hline Brijač (barbier) & 17 \\
\hline Ljekarnik (spitier) & 8 \\
\hline Sabljar (spidier) & 3 \\
\hline Trgovac (mercanto, mercer) & 11 \\
\hline Bačvar (boter, botero) & 5 \\
\hline Kamenorezac (tagliapietra) & 2 \\
\hline Kovač (fauro) & 13 \\
\hline Mesar (becher, mezzelaro) & 15 \\
\hline Krojač (sartor) & 22 \\
\hline Tkalac (tesser) & 2 \\
\hline Barkarol & 1 \\
\hline Postolar, opančar (calegher, calcetto), cokular (zoç̧aler) & 18 \\
\hline Limar (stagner) & 2 \\
\hline Kožar, krznar (pelicier) & 11 \\
\hline Veslar (remer) & 4 \\
\hline Pitur, slikar (pi(s)tor) & 1 \\
\hline Zlatar (orese) & 10 \\
\hline Klobučar, šeširdžija, kapar (bereter) & 2 \\
\hline Mlinar (moliner) & 4 \\
\hline Gostioničar (ostier) & 1 \\
\hline Sedlar (seller) & 1 \\
\hline Nadglednik zidara (protto del mureri) & 1 \\
\hline Nadglednik kovača (protto di fauri) $)^{110}$ & 1 \\
\hline Proto (protto) nadglednik - nije navedeno o kojem zanimanju je riječ & 4 \\
\hline Sopramasser (nadglednik imanja, rukovatelj dvopekom i barutom) & 2 \\
\hline Dvornik & 1 \\
\hline Majstor (kućni - maistro) & 5 \\
\hline Salamajstor (salmistrier) & 1 \\
\hline Sobar/sobarica (camarier/a) & 2 \\
\hline Organista - orguljar & 1 \\
\hline
\end{tabular}

110 Više o ulozi nadglednika u javnim radovima vidi Zdenko Dundović, Bratovština kovača u Zadru i njezina matrikula iz 15. stoljeća, Povijesni prilozi, 38, Zagreb, 2019., 56, 229 - 160. 


\begin{tabular}{|l|c|}
\hline Koralist (choraglista) & 2 \\
\hline Paron (brodovlasnik) ${ }^{111}$ & 13 \\
\hline Garzon sopra marciliana da paron $^{\prime}$ & 1 \\
\hline Obrtnici nepoznatog zanimanja (nije upisano) ${ }^{112}$ & 278 \\
\hline Sluga, sluškinja (serva, servian, servitor, familiar, fantesca) & 59 \\
\hline Nena (njegovateljica djece) & 12 \\
\hline Ribari (pescadori, pescatori) & 21 \\
\hline Mornari (marinero) & 8 \\
\hline Težak (zappador) & 79 \\
\hline Gaštaldi u crkvi & 2 \\
\hline Ukupno & 667 \\
\hline
\end{tabular}

TABLICA 7. Civilne vlasti, javni službenici i članovi njihovih obitelji (Izvor: HR-AZDN, Zadar, MKU 1597.-1917.)

\begin{tabular}{|l|c|l|}
\hline Zanimanje & $\begin{array}{l}\text { Broj pripadnika civilnih vlasti i } \\
\text { članova njihovih obitelji koji su } \\
\text { upisani u MU }\end{array}$ & Mjesta pokopa \\
\hline Providur & 2 Tiepolo $^{113}$ i Canal $^{114}$ ) & Katedrala (1); Sv. Frane (1) \\
\hline $\begin{array}{l}\text { Upravitelj policije (governator } \\
\text { della milicia) }\end{array}$ & 4 & Sv. Dominik (1); Sv. Frane (3) \\
\hline $\begin{array}{l}\text { Pomoćnik kneza za kazneno } \\
\text { pravo (criminalist) }\end{array}$ & 1 & Sv. Marija (1) \\
\hline $\begin{array}{l}\text { Upravitelj konjice (providitor di } \\
\text { cavalli) }\end{array}$ & 1 & Sv. Dominik (1) \\
\hline $\begin{array}{l}\text { Upravitelj bez navoda (oznake) } \\
\text { čega }\end{array}$ & 5 & $\begin{array}{l}\text { Sv. Frane (3); Sv. Ilija (1); } \\
\text { Nepoznato (1) }\end{array}$ \\
\hline Prior hospitala & 1 & Sv. Frane (1) \\
\hline $\begin{array}{l}\text { Pisar na brodu kao cancilier } \\
\text { (scrivan) })^{115}\end{array}$ & 1 & Katedrala (1) \\
\hline
\end{tabular}

111 Paron može značiti brodovlasnik, ali i služba na mletačkoj galiji. Ovdje se ne može odrediti o čemu je riječ, najvjerojatnije u značenju brodovlasnik. Mario NANi Mocenigo, Storia della marina veneziana: da Lepanto alla caduta della Repubblica, Roma, 1935.; reprint: Venezia, 1995., 42 - 45; Danilo KLeN, Galijoti i brodovi na vesla u našoj prošlosti, Pomorski zbornik, sv. 1, ur. Grga Novak i Vjekoslav Maštrović, Zagreb, 1962., 136 - 139; Lovorka ČoRALIĆ, Mletačka kažnjenička galija Dolfino, njezin upravitelj Šibenčanin Dujam Franjo Zak Mišević i hrvatski galijoti (1774.-1778.), Povijesni prilozi, 34, br. 48, Zagreb, 2015., 129 - 150; Lovorka ČorAlıć, Služba na galijama u XIV st. u Zadru, Radovi Zavoda za povijesne znanosti HAZU u Zadru, br. 36, Zadar, 1994., 247. - 260.

112 Nose ispred imena kraticu Mo (Maestro, mistro, meser), ali im nije upisano zanimanje.

113 Almoro Tiepolo providitor generale in Dalmatia et Albania di terre et mare, pokopan 27. 4. 1597. u Katedrali.

114 Augustin da Canal providitor generale in Dalmatia et Albania di terre et mare nakon što je bio izložen u Katedrali, pokopan je 28. 9. 1612. u crkvi sv. Frane.

115 Mario Nani Mocenigo, Storia della marina veneziana: da Lepanto alla caduta della Repubblica, 32; L. Čoralıć, Mletačka kažnjenička galija Dolfino, njezin upravitelj Šibenčanin Dujam Franjo Zak Mišević i hrvatski galijoti (1774. - 1778.), 129 - 150. 


\begin{tabular}{|l|c|l|}
\hline Notar - nodaro & 1 & Sv. Frane (1) \\
\hline Sekretar, tajnik (secretario) & 2 & Sv. Donat (1); Katedrala (1) \\
\hline Činovnik (offitiale) & 1 & Sv. Dominik (1) \\
\hline Kancelar (cancerlliere) & 4 & $\begin{array}{l}\text { Sv. Frane (2); Sv. Dominik (1); } \\
\text { Katedrala (1) }\end{array}$ \\
\hline Liječnik (fisico, eccelente dottor) & 3 & Sv. Frane (2); Katedrala (1) \\
\hline Doktor bez navoda čega & 4 & $\begin{array}{l}\text { Sv. Frane (2); Sv. Dominik (1); } \\
\text { Sv. Marija (1) }\end{array}$ \\
\hline Pravnik (rettor in legge) & 1 & Sv. Marija (1) \\
\hline Sanitarni nadzornik & 1 & Sv. Frane (1) \\
\hline Pomoćnik doktora & 1 & Katedrala (1) \\
\hline Ukupno & 33 & \\
\hline
\end{tabular}

\section{Pripadniciklera}

TABLICA 8. Svećenici, redovnice, klerici i članovi njihovih obitelji (Izvor: HR-AZDN, Zadar, MKU 1597.-1917.)

\begin{tabular}{|l|c|}
\hline $\begin{array}{l}\text { Svećenici, redovnice, klerici i članovi njihovih } \\
\text { obitelji }\end{array}$ & $\begin{array}{l}\text { Broj pripadnika svećenika, redovnika i redovnica } \\
\text { i članova njihovih obitelji koji su upisani u } \\
\text { Maticu umrlih }\end{array}$ \\
\hline Svećenici koji djeluju u Zadru & 78 \\
\hline Svećenici iz okolnih župa & 5 \\
\hline Redovnice & 53 \\
\hline Klerici & 5 \\
\hline Kapelani u vojsci & 2 \\
\hline Ukupno & 143 \\
\hline
\end{tabular}

\section{Vojska}

U maticu je upisano ukupno 424 članova vojnih posada i članova njihovih obitelji, od čega viših časnika (admirali, generali, kapetani, kavalieri itd.) i članova njihovih obitelji 132, običnih vojnika (stradioti, mornari na vojnim brodovima itd.) i članova njihovih obitelji 258, članova vojnih posada (sopracomiti, comiti, bubnjari, trubači, razni obrtnici, kapelan i sl. $)^{116}$ i članova njihovih obitelji 20, dok je zabilježeno 14 galiota. ${ }^{117}$ Među vojnicima vjerojatno ima i veći broj ubijenih te

116 Mario Nani Mocenigo, Storia della marina veneziana: da Lepanto alla caduta della Repubblica, 32, 33; Lovorka Čoralıć, Mletačka kažnjenička galija Dolfino, njezin upravitelj Šibenčanin Dujam Franjo Zak Mišević i hrvatski galijoti (1774.-1778.), 129 - 150.

117 Danilo Klen, Galijoti i brodovi na vesla u našoj prošlosti, Pomorski zbornik, sv. 1, ur. Grga Novak i Vjekoslav Maštrović, Zagreb, 1962., 136 - 139; Lovorka ČorALIć, Mletačka kažnjenička galija Dolfino, njezin upravitelj Šibenčanin Dujam Franjo Zak Mišević i hrvatski galijoti /1774.-1778.), 129 - 150; Lovorka Čoralić, Služba na galijama u XIV st. u Zadru, 247 - 260. 


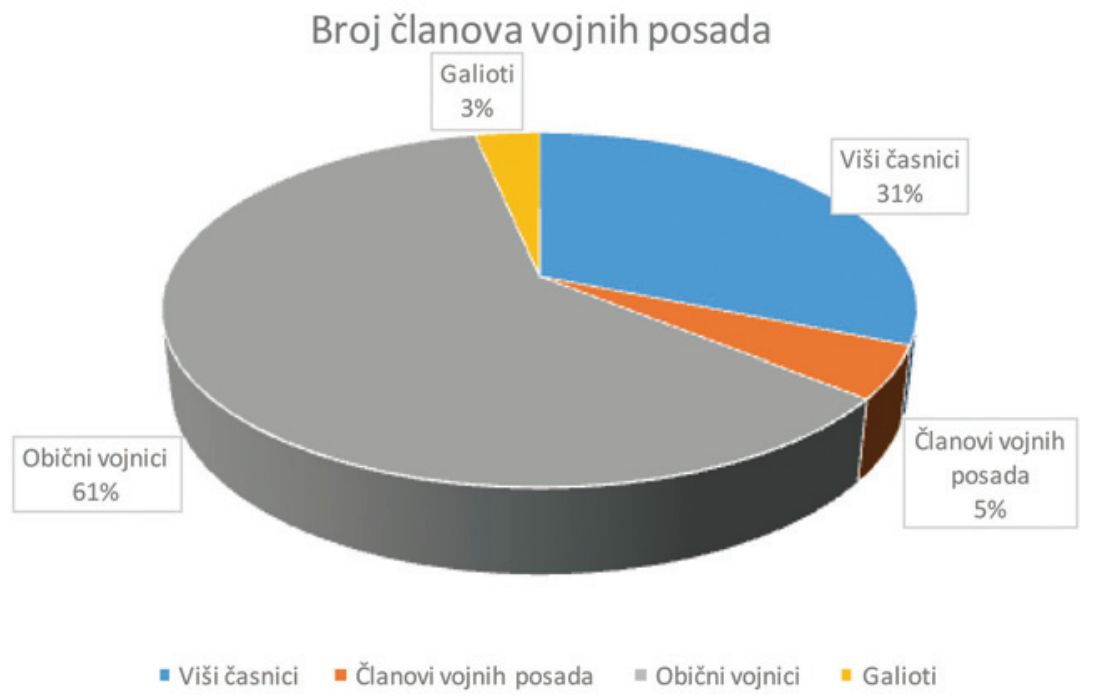

Grafikon 2. Broj članova vojnih posada upisanih u maticu umrlih. (Izvor: HR-AZDN, Zadar, MKU 1597.-1917.)

nestalih (što je samo katkad zabilježeno u matici), a među njima se prvima često širila neka zarazna bolest pa je pa je vidljivo da je u kratkom razdoblju umrlo 19 vojnika kapetana Todinija. Od 4. listopada do 12. studenog upisano je 17 vojnika te još dva do 10. svibnja 1597. U vremenu od 24. rujna do 3. studenog 1598. umrlo je 16 osoba iz jedinice kolonela Pecaronija. U razdoblju od 21. listopada 1599. do 22. siječnja 1600. umrlo je 13 vojnika iz jedinice kapitana Givannibattiste de Viterba. Većina umrlih iz ovih postrojbi pokopana je u crkvi sv. Frane.

Članovi vojnih posada uglavnom su se pokapali u svim većim gradskim crkvama. Više od trećine pokopa bilo je u crkvi sv. Frane (161 ukop - 37,97 \%), slijede Sv. Ilija (70 ukopa -16,5 \%) i Sv. Dominik (27 ukopa - 6,37 \%). Ukupno su zabilježena 424 ukopa članova vojnih posada. Sabalich piše da su heretici bili pokapani u jame na Brodarici ${ }^{118}$ pa je to vjerojatno u broju onih gdje župnik nije zabilježio mjesto pokopa, tj. mjesto pokopa je nepoznato. 
TABLICA 9. Mjesto pokopa članova vojnih posada (Izvor: HR-AZDN, Zadar, MKU 1597.-1917.)

\begin{tabular}{|l|c|c|}
\hline Mjesto pokopa & $\begin{array}{l}\text { Broj ukopa u razdoblju } \\
\text { pisanja matice }\end{array}$ & Postotak \\
\hline Sv. Dimitrije & 2 & $0,47 \%$ \\
\hline Sv. Dominik & 27 & $6,37 \%$ \\
\hline Sv. Donat & 39 & $9,2 \%$ \\
\hline Sv. Frane & 161 & $37,97 \%$ \\
\hline Sv. Ilija & 70 & $16,5 \%$ \\
\hline Sv. Ivan & 7 & $1,66 \%$ \\
\hline Sv. Katarina & 3 & $0,71 \%$ \\
\hline Sv. Krševan & 18 & $4,21 \%$ \\
\hline Sv. Marcela & 3 & $0,71 \%$ \\
\hline Sv. Marija & 17 & $4,95 \%$ \\
\hline Sv. Mihovil & 3 & $0,71 \%$ \\
\hline Sv. Nikola & 9 & $2,12 \%$ \\
\hline Sv. Roko & 2 & $0,47 \%$ \\
\hline Sv. Silvestar & 7 & $1,66 \%$ \\
\hline Sv. Stjepan & 24 & $5,66 \%$ \\
\hline Sv. Stošija - Katedrala & 21 & $4,95 \%$ \\
\hline Nepoznato (nije upisano mjesto pokopa) & 11 & $2,59 \%$ \\
\hline
\end{tabular}

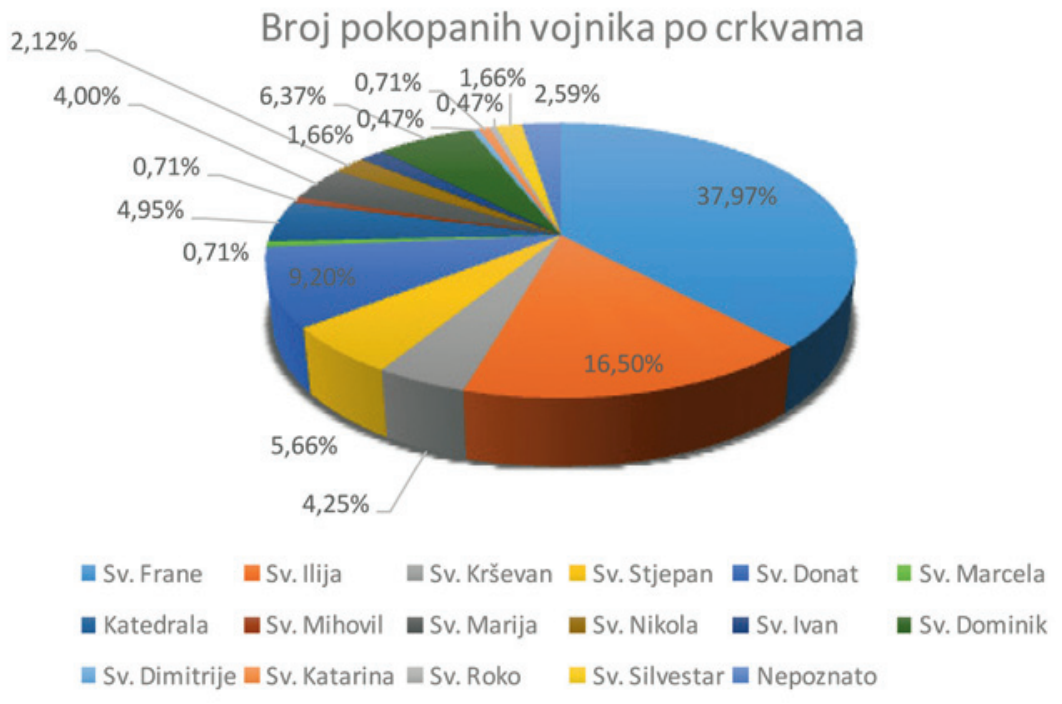

Grafikon 3. Broj pokopanih vojnika po crkvama (Izvor: HR-AZDN, Zadar, MKU 1597.-1917.) 


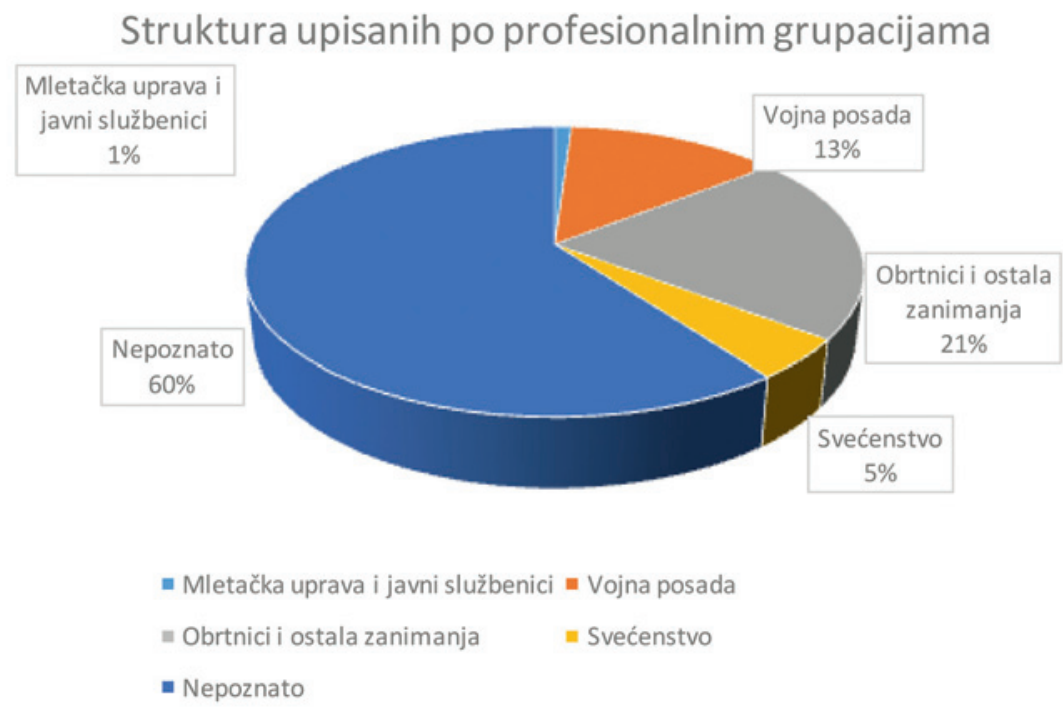

GRAFIKON 4. Struktura upisanih po profesionalnim grupacijama (Izvor: HR-AZDN, Zadar, MKU 1597.-1917.)

\section{UMRLE OSOBE PODRIJETLOM IZ MJESTA IZVAN ZADRA}

Ukupan broj umrlih osoba koje su privremeno ili trajno prebivale u Zadru, a kojima je upisano mjesto podrijetla, jest 800, od čega ima najviše Albanaca koji su najčešće zapisani kao članovi vojnih posada.

$S$ obzirom na opasnost od upada Osmanlija te blizinu mletačko-osmanske granice, u Zadar su se, osim već trajno naseljenih Varošana unutar gradskih bedema, sklanjali i stanovnici mjesta najbližih Zadru poput Bokanjca (42), Grusa (46), ${ }^{119}$ Bibinja (29), Dračevca (32), a koji su bili u stalnoj opasnosti.

119 Za župu Briševo (tada župa Grusi) ostala je iz ovog razdoblja samo glagoljska matica vjenčanih od 1613. do 1630. godine. Pavao Kero, Popis glagoljskih kodeksa zadarske nadbiskupije, (2. izdanje), 23; Pavao Kero, Grozdana Franov-ŽIvković, Svetko UšalJ, Glagoljske matice krštenih i vjenčanih župe Gospe od Ružarija u Grusima 1613. - 1824., Zadar, 2014.. Od 1613. do 1615. u samom je mjestu sklopljeno 8 brakova pa možemo pretpostavljati da je unatoč turskoj opasnosti barem dio stanovnika ostajao živjeti u tom mjestu, dok se dio sklonio u grad. 
TABLICA 10. Mjesta izvan Zadra odakle su umrle osobe (Izvor: HR-AZDN, Zadar, MKU 1597.-1917.)

\begin{tabular}{|l|l|c|}
\hline Područje & Mjesto podrijetla & $\begin{array}{c}\text { Broj } \\
\text { osoba }\end{array}$ \\
\hline \multirow{5}{*}{ Današnji dijelovi Zadra } & Bokanjac $^{120}$ & 42 \\
\cline { 2 - 3 } & ${\text { Crno }(\text { Cerno })^{121}}$ & 2 \\
\cline { 2 - 3 } & Diklo $^{122}$ & 7 \\
\cline { 2 - 3 } & Dračevac zadarski (Malpaga) / Zdračevac $^{123}$ & 32 \\
\cline { 2 - 3 } & ${\text { Chaverliza (Hovrljica })^{124}}^{125}$ & 2 \\
\cline { 2 - 3 } & Puntamika / Pontamika $^{125}$ & 4 \\
\cline { 2 - 3 } & Ukupno $^{126}$ & 29 \\
\hline \multirow{2}{*}{ Zadarsko područje } & Banj $^{126}$ & 1 \\
\cline { 2 - 3 } & Bibinje $^{127}$ & \\
\hline
\end{tabular}

120 Stefan fameio; Lucija, kći Vukaša; Suranovića; Stana Račića; Petar, sin Pavla Surgatovića; Margarita, žena Šimuna Meštrovića; Katarina Koštrovića; Anica, kći Zorzija Gunjića (Gugnicha); Petar Ratar; Kći Petra Ratara; Lorenzo Piva; Lucija Mesnića; Zorzi Radošinović; Karlo; Toma Surgatović; Marko Čavlović; Šimun Meštrović; Mate Deresko (Deresco); Katarina Stojmilovića; Peppa Sisera; Mate Surgatović; Margareta Stojmilovića; Vid Meštrović, ubijen; Lucija Lakustrića; Zagica Rataića; Vuko, sin Jerolima Mrzlića, težak; Ana, kći Stipana Surgatovića; Dona Jelica Gunjića; Madalena Cijaflovića; Madalena, žena M. Karanovića iz Bokanjca; Ivan Meštrović; Franica, kći Vida Lakuštrića; Kata Karanovića; Miho Sargatović; Ursa Merkićeva (Mrkićeva - Merchiceva); Petar Pece (Peç̧e); Elena, kći Pece (Peçce), pizzocara; Lucia, žena Pavla Ratanjića; Padre fra Paulo Meštrović; Dona Katarina od Marka Čavlovića; Bartul Čavlović; Marina Mahadić.

121 Madalena.

122 Pavle Grandešić; Margareta Barčina; Gašpar Višić; Agnia Bolulovića; Šimun Višić; Jaga, kći Matija Božičevića; Ante Hragić.

${ }^{123}$ Mara Kosinogova; Mirković; Grgo Radulov; Gašpar Radulović; Don Ivan Vodopija, župnik Dračevca; Katarina Poljanka; Toma Kosovac; Katarina Spaletova; Lucija Devića; Marko Kosovac; Grgo Ferkašić; Katarina Dević; Gašpar Babić; Jurašin Dević; Pavle Kosovac, ubijen; Elena Kosinogovića; Šimun Šišić; Petar Pelota; Miho Juričin; Elena Farkašića; Jerolima Vodopijića; Bartolomeo Čarvarić; Katarina Foloferna; Andrija Kosovac; Grgo Červarić; Marica p. Andrije Kosinoga; Grgo sin Tomasa Kosovca; Jure Červarić; Donna Anica Červarića; Šimun Kosinoga; Ivan Dević.

124 Šimun Mesnić; Agnia Maštrovića. Po Bianchiju Hovrljica je selo i brdo koje se nalazi u blizini Gospe od Maslina. C. F. BiAnchi, Kršćanski Zadar, II dio (prijevod na hrvatski jezik izvornika na talijanskom jeziku iz 1879.), Zadar, 2011., 359. Vjerojatno predio ispod današnjeg zadarskog naselja Bokanjac.

125 Petar od Vukaše; Nikola; Elena Mogriševića; Jure Cerodol.

126 Petra iz Banja.

127 Anica, žena Nike Seljačića (Seliacich); Ivan Špadinić (Zuanne Spadinich); Kata Piljušićeva; Zorzi Barzovich; Vuko Sikirić; Antonio Dorić; Grgo Margetić; Matij Margitić; Vukava Margitić; Margarita Margitića; Garobad; Katarina Margetića; Nikola Piljušić; Šimun, sin Nikole Jadrića; Petar Obad; Elena Špadinića; Mate Špadinić; Miho, sin Šimuna Špadinića; Dona Agnia Brzovića; Dona Jeronima Brzića; Katarina, p. Vuke Stojmilovića; Jerolim Margetić; Martin Loničić; Martin Brižić; Stipan Barzović; Helena, kći Antonija Dorića; M. Šimun Jadrić; Jure Jadrić; Margarita, žena Šimuna Špadira; 


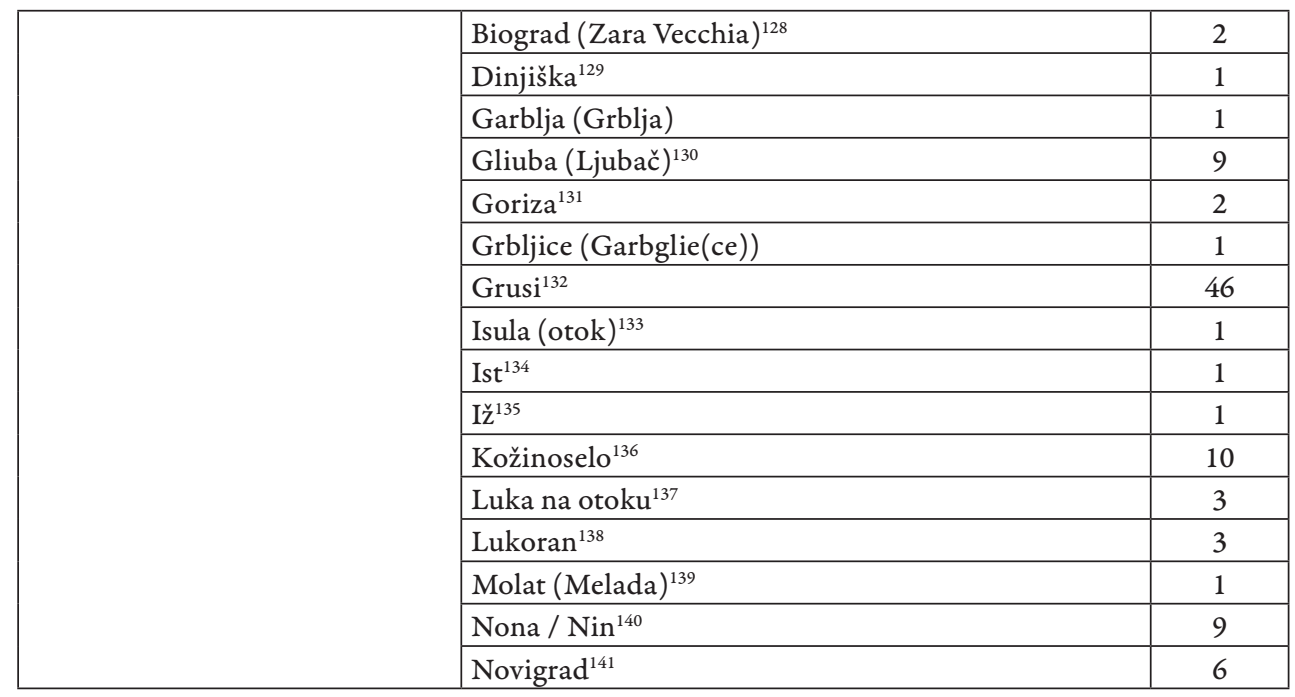

Vučen Petrović; Zorzi, sin Petra; Dragiša Panić; Jedna osoba iz Gorice; Ivan Barčinović; Mile Pavić; Jure Perković; Kata Andrijića; Jakica, kći M. Petra.

131 Martin; Ivan Udovičić.

132 Buzalović; Zorzi Laloević; Andrija Račić; Dona Dorka; Klara Čobanića; Šimun Račić; Tomas Ružić (Rusich); Bartolomeo Kadinović; Ivan Marcolić; Don Frane Baškotović, župnik Gruha; Nikola Stojčić, ubijen od Turaka; Luka Jelačić; Bartolomej Rade(1)jević; Vuko, sin p. Jure Lalkovića; Ivan Radeljević; Mile Ladić; Kajka Ladića (Chaica), možda Kaljka - žena iz Kali; Barica, p. Anoria iz Gruha; Jure Nonković; Mara Račića; Mate Milatović; Šimun Račić, cavalesier; Dorotea, kći Ivana Račića; Pavle, sin Nikole Čobanića; Dona Katarina; Tri vojnika (soldati valosori) iz Grusa (Gruha), ubijeni od Turaka: Jurašin Zoić, Andrija Račić, Filip Marcolić; Marta, žena od stenuo Jure Milatovića; Cvitko Versatović; Dunica, žena Petra Pagora; Katarina, udovica p. Mirka (Pace) Ružića; Marko Karšulović; Dona Margarita, udovica p. Cvitka; Ivan Ćirin; Ivan Ćirinović; Marko Rubić; Miho Čobanović; Ivan Siljanović; Andrija Ćirin; Mate Karančić; Tomas Marcolić; Agica, žena Ivana Ćirina; Ivan Ladić; Bartul Stoić; Martin Marcelić.

133 Margareta, siromašna (povera).

134 Katarina Panovića, sluškinja (serva).

135 Madalena.

136 Matio Bilan; Dolla, žena Vukaša; Pavle, sin Puše (Pussa); Marko Šumić; Miho Pušić (Pussich), ubijen; Grgo Vel(j)anović; Agnia, žena Pavla Beloevića; Mate Bogilović; Pavle Biloev; Martin Varan.

137 Mate Kašić; Oratio; Sig capo Jeronim Pučirić.

138 Matija, kći Šime iz Lukorana, officier del Clarisimo conte; Katarina, serva; Margareta, žena Šimuna ostiera - gostioničara.

139 Nico galeott.

140 Clerico di mons oratio Bellotti vesc di Nona; Rdo Mons Horatio Bellotti, vescovo de Nona (biskup Ninske biskupije); Martin Lučić, ubijen; Bartolomeo; don Šimun Vukonić, ninski vikar; Jedan stradiot; M. Simoni; Ivan soldato; Paulo.

141 Mate Oštrić; Zuane; Ivan od Jerolima, mornar (mariner); M. Petar od Ivana Valenčića deto Pestina; Jeronima, kći Ivana Valentića zvanog Pestina, mariner; Matia. 


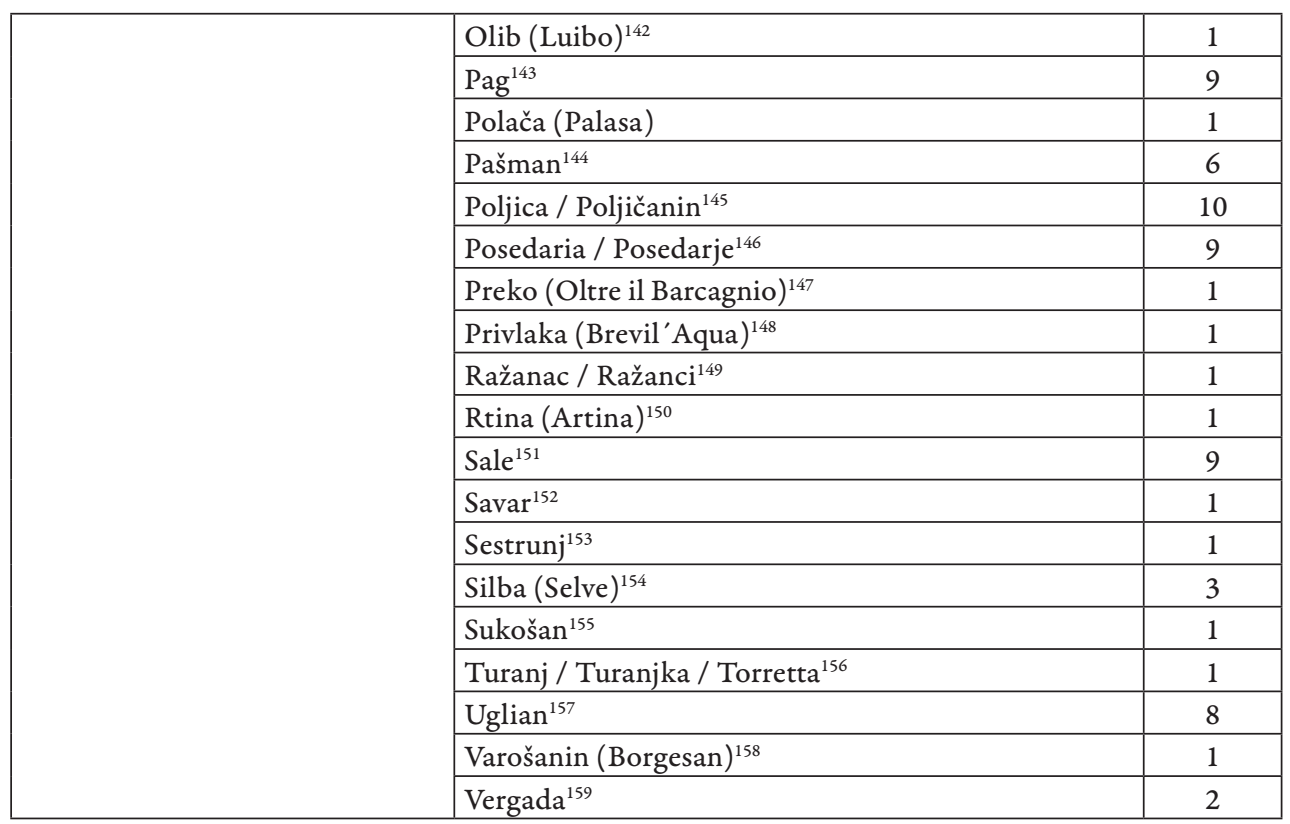

142 Lucia.

143 Donna Vicenza; Luka; Capo Barić; Zorzi Dorigo; Bartulić, alfier; Fumia; Marina; Capo Paulo, bombardier; Petar, sin M. Paula Terza; Lorenza, kći Ivana Čučkovića.

144 Kata; Andrija, krojač (sartor); Ursa; Agnia, serva; Margareta Benčića, serva; Lucija Mađerića.

145 Blaž Ljubanić; Matio, stradiotto; Zorzi, stradiotto; Ivan; Nikola Advokatović; Strenuo Tadija Milošević, alfier; Marica, žena Ilije Gvozdanovića; Petar Sladoević; Ivan Poljičanin; Pavle, sin Jure Sipopilovića, soldato.

146 Žena conte Janka; Kći conte Janka; Kći contea Michaela; Stefano, sin contea Michaela; Donna Lucia, majka Zorzija de Posedaria; Katarina; Nikola Umiljenović; Conte Janko; Strenuo capo Gašpar.

147 Ivan Krstić (Cherstich).

148 Tadija Umiljenović.

149 Nikola Ugarković, morlah.

150 Ivan, sin Mihe Lilića.

151 Andrija; Jelica; Donna Luca Puhova; Margarita Čifčića; Mandalina Beršića; Katarina, žena Grge Zuanića / Žuvanića; Mastro Šimun Ružić iz Sali, habitante a Zara; Agnija, žena Grge Lučinovića; Elena Lisičina.

152 Isabeta, kći M. Franca prote.

153 Marta Radovanića.

154 Luka; Anto Zuccaro, sin Marka Damianija, soldato; Matia, žena parona Grge Arbanaševića.

155 Don Jakov, kapelan Sukošana (San Kasijan).

156 Kata.

157 Jedna žena iz Ugljana; Šimun Matešić; Katarina, žena Martina Puchara iz Ugljana; Dobra; Rdo Padre fra Luka; Elena Metiljica (Mettiglica); Ursa Likočevića; Katarina Boletića.

158 Margarita p. Šimuna Meštrića.

159 Ivan, nećak Rda Mons. Simona; Fra Simon Vergada. 


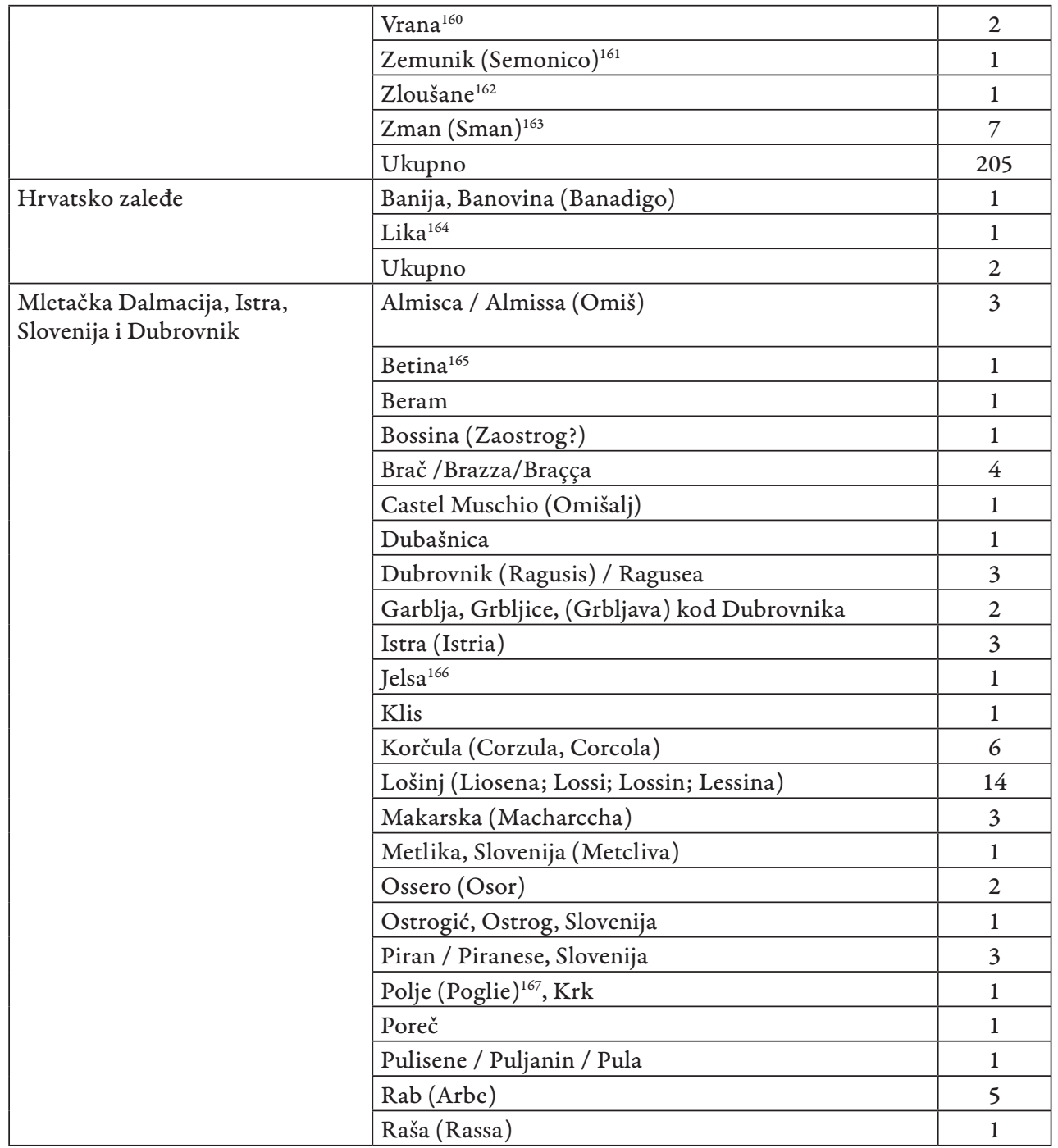

160 Jerolima, žena Mache (Maće) iz Vrane; Paulo.

161 Zorzi Sirkovich.

162 Grgo Stojčić. Zloušane je bilo selo između Bibinje i Sukošana. C. F. Bianchi, Kršćanski Zadar, II dio, 356; Ivna ANZulović, Razgraničenje između mletačke i turske vlasti na zadarskom prostoru 1576. godine, nakon Ciparskog rata, Zadarska smotra, 1-3, Zadar, 1998., 53 - 108.

163 Pater fra Šimun Hromičić; Ante Činčević; Ursa Bilavka (Bilavchia); Draga Bulina; Madalena, kći Ivana Store, Šanto, mesar.

164 Elena, paziteljica djece (nena).

165 Grgo Šišiević (Shischievich).

166 Ivan Mariani.

167 Andrija Marinović. 


\begin{tabular}{|c|c|c|}
\hline & Rijeka (Fiume) & 2 \\
\hline & Rovinj / Rovignese & 1 \\
\hline & Sebenico, Šibenik, Sebenzan, Sibenich & 33 \\
\hline & Segnia (Senj) & 1 \\
\hline & Spalato / Spalatino, Split & 9 \\
\hline & Stara cesta, Slovenija & 1 \\
\hline & Trogir / Trau & 11 \\
\hline & Veglia-Krk & 3 \\
\hline & Vodice & 1 \\
\hline & Župa, općina Zagvozd & 2 \\
\hline & Ukupno & 127 \\
\hline \multirow{29}{*}{$\begin{array}{l}\text { Venecija i Apeninski poluotok, } \\
\text { Sicilija }\end{array}$} & Allinazi? & 1 \\
\hline & Anchonitano; Ancona / Ankona & 8 \\
\hline & Ascoli / Ascola (u Markama) & 5 \\
\hline & Asola (provincija Mantova u Lombardiji) & 1 \\
\hline & Assisi (Asiz) & 1 \\
\hline & Bari & 2 \\
\hline & $\begin{array}{l}\text { Bartolomea (Villa Bartolomea) - provincija Verona, } \\
\text { regija Veneto }\end{array}$ & 1 \\
\hline & Bellona, provincija Caserta, regija Campania & 1 \\
\hline & Bergamo / Bergamisco / Bargamasco (Lombardija) & 9 \\
\hline & Biandronno, provincija Varese, regija Lombardija & 1 \\
\hline & Bologna / Bolognez (Emilia-Romagna) & 5 \\
\hline & Brasenza & 1 \\
\hline & Breša (Bressa) & \\
\hline & Brindici / Brendici & 2 \\
\hline & Bruzzi (provincija Piacenza, regija Emilia-Romagna) & 1 \\
\hline & Buzzi (provincija Ravenna, regija Emilia-Romagna) & 1 \\
\hline & Camignone (provincija Brescia) & 1 \\
\hline & Camisano Vicentino (provincija Vicenza, Veneto) & 1 \\
\hline & Canino - u provinciji Viterbo, regija Lazio. & 1 \\
\hline & Caselmola (Sicilija) & 1 \\
\hline & $\begin{array}{l}\text { Castelvechio da Pesaro - provincija Pesaro regija } \\
\text { Marche }\end{array}$ & 1 \\
\hline & $\begin{array}{l}\text { Castel (di) } \mathrm{Ru} \text { (bbia) (provincija Gorica, Friuli- } \\
\text { Venezija) }\end{array}$ & 1 \\
\hline & San Micheli, provincija Pesaro e Urbino, Marche & 1 \\
\hline & Castel Zifre & 1 \\
\hline & Cesena, pokrajina Forli-Cesena, Emilia-Romagna & 1 \\
\hline & Cividal di Belu & 2 \\
\hline & Chioza & 3 \\
\hline & Chomachio, provincija Ferarra, Emilia-Romagna & 1 \\
\hline & Coalonga & 1 \\
\hline
\end{tabular}




\begin{tabular}{|l|c|}
\hline Cremona & 7 \\
\hline Crenna, Varese, Lombardija & 2 \\
\hline Este, provincija Padova, Veneto & 3 \\
\hline Fabriano & 1 \\
\hline Fano, provincija Pesaro i Urbino, Marche & 1 \\
\hline Ferimani & 1 \\
\hline Ferrarra / Ferraresse & 8 \\
\hline Fiandra & 1 \\
\hline Fiorentino & 2 \\
\hline Fiorenza (Firenca) & 2 \\
\hline Forte da Campagna & 1 \\
\hline Forli (Amilia-Romagna) & 1 \\
\hline Fossanbrone (provincija Pesaro e Urbino, Marche) & 1 \\
\hline Gandona (valle di Gandona) & 1 \\
\hline Gatti (regija Asti, Piemonte) & 1 \\
\hline Gardinale (Ville di Gardinale) & 1 \\
\hline Genoa (Đenova) / Genova & 3 \\
\hline Goritia / Goricia & 1 \\
\hline Grotte (Castellana Grotte, provincija Bari, Apulia) & 1 \\
\hline Ischia & 1 \\
\hline Legnano, pokrajina Milano & 1 \\
\hline Lodi, Lombardija & 1 \\
\hline Macerata, Marche & 1 \\
\hline Mantova & 1 \\
\hline Maran, pokrajina Trentino, Južni Tirol & 1 \\
\hline Marke & 7 \\
\hline Massa, Toskana & 2 \\
\hline Milanese; Milano / Milan & 2 \\
\hline Modena & 1 \\
\hline Monte Albotto & 1 \\
\hline Monte Beluna, Treviso, Veneto & 1 \\
\hline Monte Cicardo & 1 \\
\hline Monte Merli & 1 \\
\hline Monte Triascone & 1 \\
\hline Musso, Como, Lombardija & 1 \\
\hline Napolitano / Napoli & 1 \\
\hline Orzi(nuovi), Brescia, Lombardija & 1 \\
\hline Osimo, Ancona, Marche & 1 \\
\hline Padova; Padua; Paduano & 1 \\
\hline Pavia & 1 \\
\hline Palermo & 1 \\
\hline Pelegrino & 1 \\
\hline
\end{tabular}




\begin{tabular}{|c|c|c|}
\hline & Pecolta Nova & 1 \\
\hline & Perminjano (Permigiano) & 1 \\
\hline & Pesaro & 3 \\
\hline & Pistoia, Toskana & 1 \\
\hline & Pontremoli, Massa i Carrara, Toskana & 1 \\
\hline & Pulja / Puglia (Apulia) & 1 \\
\hline & Racanati, regija Marche & 1 \\
\hline & Ravena & 4 \\
\hline & Rimini & 3 \\
\hline & Rubiana, Torino, Pijemont & 1 \\
\hline & San Bernardino & 1 \\
\hline & $\begin{array}{l}\text { San Casiano regija Marche (osoba stanuje u } \\
\text { Marignanu, tj. S. Giovanni di Marginano, Rimini, } \\
\text { regija Emilia Romagna) }\end{array}$ & 1 \\
\hline & San Genese, Južni Tirol & 1 \\
\hline & San Marco & 1 \\
\hline & Sassi di Matera, provincia Basilicata & 1 \\
\hline & Sicilia (Cicilia) & 1 \\
\hline & Soncino, provincija Cremona, Lombardija & 2 \\
\hline & Talijan / Talijanka (Taliana) & 2 \\
\hline & Terra & 1 \\
\hline & Terragio, Treviso & 1 \\
\hline & Trento & 4 \\
\hline & Treviso / Trevisano & 4 \\
\hline & Udine / Udene & 2 \\
\hline & \begin{tabular}{|l|} 
Urbino \\
\end{tabular} & 2 \\
\hline & Venecian; Venecia & 48 \\
\hline & Viterbo, regija Lacio & 1 \\
\hline & Verona & 8 \\
\hline & Vicenza & 4 \\
\hline & Viadana, Mantova, Lombardija & 1 \\
\hline & Ukupno & 253 \\
\hline Mletačka Albanija i Mletački & Albanija / Albaneze ${ }^{168}$ & 119 \\
\hline posjedi na Levantu & Antinari / Antivari (Bar) & 3 \\
\hline & Budva & 3 \\
\hline & Candia, grad na Kreti, Grčka & 7 \\
\hline & $\begin{array}{l}\text { (Castel Novi) - Herceg novi / Novo (Castelnuovo di } \\
\text { Cattaro) }\end{array}$ & 3 \\
\hline & Cataro - Kotor & 10 \\
\hline & Cefalonija (Zafalonia; Kefalonija) & 2 \\
\hline
\end{tabular}

168 Roman JeLIĆ, Stanovništvo Zadra u drugoj polovici XVI i početkom XVII stoljeća gledano kroz matice vjenčanih, 349 - 509. Mletačka Albanija obuhvaćala je područje od Boke kotorske do Drača. 


\begin{tabular}{|c|c|c|}
\hline & Cipar / Cipro & 4 \\
\hline & Charia (općina Oleni, Grčka) & 1 \\
\hline & Greco & 3 \\
\hline & Krf (Corfu) & 5 \\
\hline & Lepant & 1 \\
\hline & Maranić & 1 \\
\hline & Markovići & 1 \\
\hline & Modon & 3 \\
\hline & Montenegro (Crna gora) & 7 \\
\hline & Morea & 6 \\
\hline & Paštrović & 4 \\
\hline & Perast & 3 \\
\hline & Rodon & 1 \\
\hline & Šestani & 3 \\
\hline & Tirana (Tarana) & 1 \\
\hline & \begin{tabular}{|l|l} 
Ulcinj (Dulcigno, Dolcigno) \\
\end{tabular} & 6 \\
\hline & Ukupno & 197 \\
\hline Ostalo & Francese & 3 \\
\hline & Macedonia / Makedonija & 1 \\
\hline & Srbac, BiH & 1 \\
\hline & Tedesco (Nijemac) & 5 \\
\hline & Ukupno & 16 \\
\hline Ukupno & & 889 \\
\hline
\end{tabular}

\section{PREZIMENA GRAĐANA I PUČANA KOJIMA NIJE NAVEDENO DA SU IZ NEKOG MJESTA IZVAN ZADRA}

Većinu stanovnika čine Zadrani ili osobe kojima nije upisano porijeklo $(71,89 \%) .{ }^{169}$

U matici se javljaju sljedeća prezimena osoba kojima nije upisano porijeklo: Albrisio, Alorizzi, Ambrošić, Argičić, Argličić, Armani, Armanoni, Azalin, Azzalin, Babčić, Babin, Babovčić, Babušić zvani Čičarela, Bačičiević, Badeša, Badinić, Bagatinova, Bagavčić, Bagin, Bagolić, Bahor, Baisanov, Bajčinović, Bakalari, Bakota, Bakotin, Balarin, Balašić, Baldazara, Baloban zvani Perlica, Baraković, Barbašić, Barbiričić, Barbora, Bartulini, Bartulović, Bastašić, Bastašpača, Bastelli, Bataldini, Batarić, Batina, Batković, Batorić, Batošić,

169 Mnogima nisu upisana prezimena, već samo osobno ime npr. madona Gratia, žena m. Bate brijača ili Marko bačvar. U popisu ovih prezimena nije obuhvaćeno plemstvo i vojnici. Vidljivo je da su mnoga od ovih prezimena u tom razdoblju postojala u okolnim selima i na otocima. Neka od ovih prezimena i danas postoje u Zadru i okolici. 
Batović, Bautina, Bederceo, Bedina, Beđarolo, Belegno, Belloti, Benevalja, Beneventa, Benvenuti, Berničović, Bernić, Beršić zvani Bosna, Bertolini, Berzić, Bettori, Bianchi, Bianchini, Bibenov, Bigon, Bilač, Bilić, Bilulov, Biljaković, Biljušić, Bionda, Blasević/Blažević, Blazetta, Blažan/Blazan, Blažetić, Bloković, Bobetina, Boca (Bozza), Bodulić, Bodulin, Bodulo, Bogafčić, Bogavčić, Bogdanić, Bokančića, Bokunić, Bolčić, Bolković zvani Rosa, Bolzoni, Bombašić, Bon, Bonadi, Bonora, Bontusto, Borbulin, Borgo (Varošanin), Borislavić, Bornić, Borra, Bosaev, Bosateri, Bosina/Bozina, Boska, Bosna, Bosotina, Botomina, Božičević, Božić, Bragirina, Bratić, Bričić, Brieković, Briero, Brigačić, Brigočić, Britanico, Brodarić, Broskvić, Brukvica, Bruna, Brunei, Bruskandola, Bruttavecchia, Bua, Bubica, Bubnanić, Bubnarić, Bubnjanić, Bučifarovica, Budačić, Budaković, Budanović, Budinić (Budineo), Budurović, Bukinica, Bunić, Bura, Burić, Buzalović, Cago, Calić, Callalea, Callo, Campagritti, Canal, Canalane, Cancini, Candelini, Capić, Carvul, Cassari, Catalano, Cerodol, Cervelin, Chazotti, Chessa, Chifal, Chiropodi, Cincela/Činčela, Cirutti, Cochapan, Collini, Colombini, Conatti, Coreli Boria, Corner, Cortesi, Coto (Zotto), Crnošia/Crinošia, Cvitanović, Cvitić, Čačarsavin, Čačinović, Čaleta/ Caleta, Čambrlja, Čanberlja, Čečin/Čeljin, Čekić/Kekić, Čelabić, Čeludić, Červarić, Červarov, Čezić, Čičizina, Čisanić, Čobančić, Čobanović, Čobe, Čubrić, Čučević/Lučević, Čučina/Kučina, Čulina/Šulina, Čusina, Čuzadura, Ćinća (Đinđa), Ćirinović, Ćuća, Ćućin, Daba, Danić, Danieletti, Dapčo, Darić, Dašković, Dazdarić/Dazdrić, Dederčev, Delestani, Denenčinić, Derenešić, Desković, Desperčić, Desperičić, Despot, Dešković, Dević, Deviol, Dezupa, Dijanović, Dikličić, Dimitrić, Disković, Dismanić, Dlamić, Doladi, Dombra, Domjanka, Dorić, Dormissi, Dračević, Dragičević, Dragišić, Dragoljica, Drasmić, Drazmilić (Drasmileo), Dražević, Dražičević/Drašičević, Dražić, Dristonja, Driveničić, Dulčić, Duletić, Dumeralić, Dumić, Duorić, Dupinka, Dupinović, Dušmanić, Dvornikov, Fabio, Fačinića, Faiča, Faić, Faion, Faras, Farkaš, Farović, Faslitić zvani Kaičica, Feltrin, Fenulić, Feralić, Feranak, Ferenčić, Ferkašić, Ferletić, Ferlić, Fernelli, Ferrari, Ficini, Filacano, Filacenovo, Filipuzzi, Foreste, Foristico, Formenta, Forner, Fornera, Forneri, Fračić, Franković, Furlan, Furmagević, Gabelotta, Gabelotti, Gabelotto, Galelli, Galić, Galineri zvana Kokošarovica, Galo, Galov, Garbin, Gargica, Gargurević, Gargurina, Garngarić, Garofal, Gašparović zvani Uskotok, Gentili, Ginji, Giribalda, Girić, Gladović, Gluha, ${ }^{170}$ Golubković, Gorbolan, Gospodičić, Granada, Granata, Grancarić, Grando, Grego, Grešković, Grganov, Grgeša, 
Grillo, Grimani, Grimati, Groić, Grubačić, Grubelić, Grubina, Grubišić, Guarzo, Gučević, Gueri, Guerini, Guličera, Guljina, Guljinka, Gunić, Gunjović, Habazinović, Halavača, Halazinić, Harbočić, Harvatinić, Hrabar, Hrglja/ Hrelja, Humašić, Huzić, Ilijić, Ilijin, Ivančić, Ivanović, Jadrešić, Jadrukovića, Jadrulovičin, Jadrulović, Jaduković, Jadurica, Jajadurica, Jakofčić/Jakovčić, Jelačić, Jelačin, Jelčić, Jeličić, Jelovčić, Jelvin, Jera, Jivaničev, Jivanišević, Jivanošević, Jivivić, Jordani, Jugović/Gugović, Juković, Juretin, Jurgičin, Juričević, Jurjević, Jurković, Justianić, Kalafatinić, Kalić, Kapitanić, Kapotić/ Capotić, Karamanka, Karičić, Karić, Karin, Karinić, Karinović, Karpuša/ Krpuša, Karšulovica, Kašić, Katasinović, Katić, Kekić/Čekić, Kerpinić/Krpinić, Kilavčić, Klarić, Klikalina, Klovin, Kljuka (Chgliucha), Kobasarić, Koblović, Koglić/Koljić, Kogo, Kokota, Kolan, Kole, Kolonić, Komaljev, Komitović, Komorić, Koplan, Korisanić, Korisnica, Kosinoga, Kosović, Kosterić, Košarović, Koščić, Koščina, Košić, Koto(t)vina, Kovačić zvani Hanza, Kovačić, Kozomor, Kragica, Kragić, Kralj, Kraljić, Krekić/Krečić, Krstić (Karstić), Kučić, Kučipero/ Čučipero, Kučiperov, Kukovelja, Kukuć, Kureta, Kuršul, Kurtanitra, Kusadurov, Kusić/Kušić, Kusturić zvani Garibaldo, Kušičić, Kuzmić, Kužinović, Lagahnović, Laišanin, Lalić, Lališević, Lantana, Lasibaša, Latković, Lavandara, Lavara, Leča/Leka, Lelmetti, Lešić, Letinov, Libračić, Librovčić, Lignjica, Liparelić, Liparelli, Lisica, Lisičić, Lišević, Locatello, Lombardi, Longin, Loredan, Lovrinčić, Luchese, Lučavić, Lučić, Lučiša, Ludovico, Lugić, Luicoto, Lukačić, Luzetin, Lužić, Ljubačić, Ljubavac, Ljubavčić, Ljubičin, Ljubić, Ljubimira, Ljubin, Ljubinov, Macina, Mača, Mačaran, Mačarato, Maffei, Mafoević, Mafrević, Magličić, Maglić, Magnanetti, Magnanić, Mahadić, Makarović, Makarunica, Malaspina, Malašpina, Maletić, Malipijero, Malora, Maniscalci, Mankušević, Marasov, Marat, Maratina, Marcio, Marešinić, Margiača, Margitić, Mariešev, Mariević, Marinini, Marinoč, Marinoić, Marinović, Mariscello, Marislavić, Maritoni, Markalinić, Markolin, Markulin, Maroča, Maroić, Marojić, Martinčić, Martis, Martišuća, Martorella, Marzzarello, Masara, Masluč, Mastača, Mastogonjić, Mašić, Matacović, Matasović zvani Pulisan, Mateša, Matešić, Matiašev, Matković, Matuljin, Mazza, Mazzaran, Mazzarella, Medaković, Medić, Medićev, Medula (Medulić), Melaković, Merčić, Merginić/ Mrginić, Mesnić, Mesnićev, Mesodića, Mesodilić, Mesodiljić, Mestaechielli, Meštričić, Meštrić Borgesan, Meštrović, Metljiva, Mičalin, Mihaljica, Mihatov, Miheča, Mihelja, Mihin, Miklošev, Milanović, Milašević, Milić, Milićev, Milinkov, Milla zvani Zadrizlić, Millasseo, Miloš, Milušević, Mirković, Mirra, Mladičić, Močaničin, Močanić, Mogaševač, Moinić, Morea, Morganti, Morić, Morov, Mozanić, Mozićev, Murir, Mussu, Mušković, Mušunić, Mutiljić, 
Nadančića, Nadihnić, Nalešić, Negrić, Nehrucalo, Nemarić, Neziručalov, Nižić, Novačić, Novak, Novakov, Oblačina, Očalin, Opančarov, Orba, Ostojić, Oštarić, Pačić, Pačićev, Pačin, Padralović, Pagierov, Pagierović, Pagor, Palaško, Palčić, Palus, Palušev, Palzakov, Pangin, Panigetto, Panović, Papala, Paprenjak, Parenčić, Parizzon, Parola, Parunić/Parunica, Pasini, Paša, Pavić, Pečina, Pećarovica, Pederceo, Pendelić, Peričić zvani Hasan, Perina, Perlica, Perličić, Perohin, Persego/Perzago, Peruča, Peručić, Perušić, Petiarić, Petrović, Pezzetta, Pianov, Piccoli, Picollo, ${ }^{171}$ Pičin/Picin, Pićilinov, Pilicarov, Piljušić, Piva, Pleurinča, Pliskov, Plišo, Prero, Presnica, Preša, Priša, Pročin, Ptičina, Puho, Puhov, Pulišinov, Puljičica, Puljiuhović, Pupić, Raberić, Račić, Radančića, Radatović, Radičić zvani Jadrafonić, Radić, Radićev, Radimov, Radin, Radinov, Rado, Radosović, Radoš, Radošević, Radul, Radulo, Radulov, Radutović, Raefico, Raišić, Rajčić, Raličić, Ralić, Raljević, Raljićev, Ramtaniko, Raodrić, Raskov, Rassan, Rastović, Ratagić, Rataić, Ratišić, Ravnić, Referunda, Remandini, Resendi, Ribarov, Rigo, Rile, Rilinić, Rimanić, Rizmanović, Rizolić, Ročović/Roković, Rodernić, Rojčić zvani Merbegov, Rojšić, Roković/Ročović, Romagriolo, Romana, Rondačić, Ronzun zvani Smoljanović, Rosin, Rossetti, Rossetto, Rosso, Rošava, Rotačić, Rozanić, Rozičić, Rožić/Rozić, Rubica, Rudan, Rudela, Rudelić, Ruminić, Ruoinović, Rupinović, Rusić (Ružić), Rušinović zvani Juran, Ružarević, Sablja, Sagioli, Salamonea, Salamunić, Salešić, Salić/Šalić, Salmipiero, Salomonio, Samčin, Samograh, Samović, Sanglavina, Saperčić, Saračin, Sarinčin, Sarpanić, Sciavon (Skjavon), Scibor, Scrisa, Scutari, Seljakov, Sermanović, Serolanov, Serumenić, Sfitković/Svitković, Sgorbina, Siche, Sigljica, Sikirić, Simić, Sinčić, Sivčić, Skaletin, Skandali, Skoča, Skordač, Skorobić, Slipčić, Smoljan, Smoljanov, Sodarnić, Sopulić, Sortić, Spanlić, Spendić, Spiron, Spliča, Squerget, Srabanda, Stanglinov, Stangunića, Staničić, Stanišić, Starčić, Starislavić/Starislarić, Starnokošić/Sternokosić, Stasić, Stipačin, Stipačinović, Stipanić, Stipanović, Stipica, Stipičin, Stochi, Stocta, Stojčićev, Stojmekosić, Storijić, Straščić, Strašir, Strudić, Struša, Sučić, Suferko, Sumnić, Sumnja, Suppa, Surgatović, Surian, Suscolo, Sušalova, Sutulović, Svetiko, Svićarić zvani Pezdeljić, Svirac, Svirčev, Šačabaroci, Šalić, Šavić, Šibenčan, Šibor/Ščibor (Schibor), Šimaga, Šimaja, Šimaljić, Šimaljin, Šimatov, Šimatovica, Šimićev, Šimuničić, Šiša, Šišić, Škoda, Škvrljić, Šljaka, Špi(j)a, Špijić, Štria, Šumić/Sumić, Šuperko, Taljadurić, Taljindurić, Taranti, Teletina, Teletinov, Teletinović, Tenento, Tertiu, Thomassian, Tninović, Tomaničin, Tomasica, Tomasicina, Tomašica, Tonini, Torelli, Torresan, Trifoni, Trifunić,

171 Ovo je možda nadimak Grgo mali (Grego Picollo). 
Troikov, Turčić, Turčinović, Turić, Turier, Turisan, Turisela, Turković, Tutofić/ Tutović, Umašić, Vace, Valentić, Valentinić, Valsama, Vanura, Vasić, Vašilj/ Vasilj, Večin, Velanović, Velislavić, Veljačić, Veljanov, Veljanović, Ventura, Venturić, Venturini, Venzoni, Vergada, Versatović, Vertačić, Vidaković, Vidović/ Vidonić, Viković, Višić, Vitanović, Vitelli, Vlahić, Vlahović/Vlahonić, Vlašić, Vleladori, Vodančić, Vodopija, Vodopijić, Vodopijin, Vodopijinica, Voinić, Volpatto, Vrana, Vrančić, Vrsarko, Vuacci, Vučičević, Vukotić zvani Launtello, Vuksanov, Vulahin/Vlahin, Vulahović, Vulašić, Vuolpati, Zacher, Zadrislić, Zadrizlić, Zadruloni, Zakarija, Zanić, Zanini, Zanko, Zanto, Zapić detto Siena, Zarić, Zelina, Zenaro, Zeneralić, Zeneralizza, Zonfo, Zorini, Zotto (Coto), Zrinki, Zuarehović, Zuroda, Zverović, Zzaro, Žentilica, Župa/Zupa.

\section{Mjesto podrijetla stanovnika Zadra}

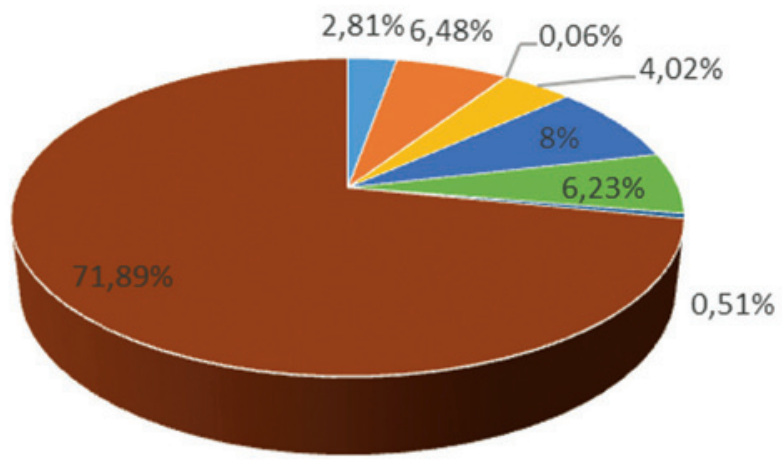

- Današnji dijelovi Zadra

- Hrvatsko zaleđe

- Venecija, Apeninski poluotok i Sicilija
- Zadarsko područje

- Mletačka Dalmacija, Istra, Slovenija i Dubrovnik

- Mletačka Albanija i Mletački posjedi na Levantu

Grafikon 5. Mjesto podrijetla stanovnika Zadra (Izvor: HR-AZDN, Zadar, MKU 1597.-1917.)

\section{ZAKLJUČAK}

U radu se nastojalo pokazati kakva je bila struktura zadarskog stanovništva krajem 16. i početkom 17. stoljeća na osnovi narativno pisane matične knjige umrlih. Analizirane su pojedine staleške grupacije. Za najviše umrlih osoba nije poznato u koju profesionalnu grupaciju spadaju (60\%). Obrtnici, pomorska i 
uslužna zanimanja sačinjavaju $21 \%$ upisanih, članovi vojnih posada $13 \%$, dok svećenstvo sačinjava $5 \%$ i mletačka uprava $1 \%$ upisanih.

Najveći broj stanovnika Zadra u vremenu pisanja ove matične knjige 1597. - 1617. čine Zadrani (iako u ovoj kategoriji ima i određen broj osoba kojima nije upisano porijeklo). Najmanje osoba dolazilo je iz područja Like i Banovine, dok su ostalo stanovništvo činile osobe iz ostalih mletačkih područja, kao i stanovništvo iz zadarskog zaleđa i otoka. Iz tih ostalih mletačkih područja uglavnom su dolazili članovi vojnih posada, dok je stanovništvo iz zadarske okolice dolazilo živjeti i raditi u Zadar, većina se trajno nastanjujući u njemu. Po popisima prezimena vidljivo je da su se pojedina sačuvala u Zadru do današnjih dana.

Pokopi su se obavljali po većini zadarskih crkava (24), s tim da su se vojne osobe najviše pokapale u crkvi sv. Frane, dok se plemstvo pokapalo najviše u crkvama sv. Frane, sv. Marije i sv. Dominika. Pučani i svećenstvo bili su pokapani u sve crkve ravnomjerno, pučani ovisno o kvartu u kojem su živjeli, dok su pripadnici crkve pokapani u crkvama u kojima su djelovali. 


\section{IZVORI I LITERATURA}

\section{IZVORI:}

HR-AZDN, I, Zadar, Matična knjiga umrlih 1597. - 1617.

HR-DAZD, Pašman, Glagoljska matica umrlih 1606. - 1679.; Pašman, Glagoljska matica umrlih 1607. - 1612.; Pašman, Glagoljska matica umrlih 1607. - 1612. HR-DAZD, Glagoljska matica umrlib Sutomisćcica 1765. do 1825.

HR-DAZD, Olib, Glagoljska matica krštenih 1652. - 1662.

\section{LITERATURA:}

Anzulović, Ivna, Razgraničenje između mletačke i turske vlasti na zadarskom prostoru 1576. godine, nakon Ciparskog rata, Zadarska smotra, 1-3, Zadar, 1998., 53 - 108.

Belicza, Biserka, Medicina i zdravstvo, u: Hrvatska i Europa, kultura, znanost $i$ umjetnost, sv. III, Barok i prosvjetiteljstvo (XVII.-XVIII. st.), ur. Ivan Golub, Zagreb, 2013., 379 - 403.

Benvenuti, Angelo, Storia di Zara (dal 1409-1797), Milano, 1944.

BertošA, Slaven, Obrti i neka ostala zanimanja u Puli od 17. do 19. stoljeća, Povijesni prilozi, 20, 21, Zagreb, 2001., 121 - 159.

Bianchi, Carlo F., Zara Cristiana, I, Zadar, 1877.

BiAnCHI, Carlo F., Kršćanski Zadar, II dio (prijevod na hrvatski jezik s izvornika na talijanskom jeziku iz 1879.), Zadar, 2011.

Bianchi, Carlo F., Fasti di Zara, Religioso-politico-civili, dall'anno $1184 \mathrm{Ar}$. Cr. Sino all' Anno 1888, Zadar, 1888.

Cvitanović, Vladislav, Bratovštine grada Zadra, Zbornik Zadar, Zagreb, 1964., 457 - 470 .

Cvitanović, Vladislav, Privilegij pomilovanja bratovštine Gospe od Sniga, Gospe od navještenja i sv. Andrije u Zadru (u 17. st.), Pomorsko zanimanje Ižana, Starine, Zagreb, 1955., knj. 5., 173 - 280.

Čola K, Nikola, Naše ribarstvo do pada Mletačke Republike, Pomorski zbornik, I i II, Zadar, 1962.

ČorALIĆ, Lovorka, Hrvatski useljenici u Mlecima, Bratovština topnika i kotorski biskup Angelo Baronio, Povijesni prilozi, 32, 44, Zagreb, 2013., 169 - 181.

ČorALIĆ, Lovorka, Izvori i literatura o bratovštinama u Dalmaciji od srednjeg vijeka do pada Mletačke Republike, Croatica Christiana periodica, 15, br. 27, Zagreb, 1991., 88 - 96. 
Čoralić, Lovorka, Mletačka kažnjenička galija Dolfino, njezin upravitelj Šibenčanin Dujam Franjo Zak Mišević i hrvatski galijoti (1774. - 1778.), Povijesni prilozi, 34, br. 48, Zagreb, 2015., 129 - 150.

Čoralić, Lovorka, Služba na galijama u XIV st. u Zadru, Radovi Zavoda za povijesne znanosti HAZU u Zadru, br. 36, Zadar, 1994., 247 - 260.

DokozA, Serđo, ANDreis, Mladen, Zadarsko plemstvo u srednjem vijeku, Zadar, 2020.

Dundović, Zdenko, Bratovština zadarskih Varošana, Zadar, 2020.

Dundović, Zdenko, Bratovština kovača u Zadru i njezina matrikula iz 15. stoljeća, Povijesni prilozi, 38, 56, Zagreb, 2019., 229 - 160.

Dundović, Zdenko, Florijevo sjemenište u Zadru - prilog poznavanju njegova otvorenja i djelovanja, Croatica christiana periodica, br. 86, Zagreb, 2020., 87 $-110$.

FiliPI, Amos-Rube, Uskočki podvig kod Mulina na otoku Ugljanu. Zadarska revija, III, br. 2, Zadar, 1954., 142 - 153.

FILIPI, Amos-Rube, Senjski uskoci i zadarsko otočje, Pomorski zbornik, knj. 2, Zadar, 1964., $579-632$.

Franov-Žıvković, Grozdana, Svakodnevni život na tursko-mletačkoj granici na području Zemunika u 17. st. na temelju dokumenata pisanih hrvatskom ćirilicom (bosanicom) i glagoljicom, Zemunik u prostoru i vremenu, ur. Josip Faričić, Zdenko Dundović, Zadar, 2016., 170 - 189.

Franov-Žıvković, Grozdana, Stanje na mletačko turskoj granici na području Vrane u 17. st. na temelju dokumenata pisanih hrvatskom ćirilicom (bosanicom) i glagoljicom, Braća Vranjani i vransko područje tijekom povijesti, Zadar, 2017., 411 - 438.

FrAnov-Žıvković, Grozdana, Glagoljica u Zadru - Glagoljski zapisi iz knjige bratovštine sv. Antuna opata 1725. - 1777., Glasilo Udruge glagoljaša Zadar Slovo Rogovsko, br. 4, Zadar, 2016., 13 - 16.

Franov-Žıvković, Grozdana, Načini evidentiranja podataka u glagoljskim matičnim knjigama pisanima do 1825. godine na zadarskom području, Povijesni zbornik - godišnjak za kulturu i povijesno naslijeđe, br. 4, God. III, Osijek, 2009., 79 - 124.

Franov-Žıvković, Grozdana, Glagoljske matice umrlih župe Rođenje blažene djevice Marije u Pašmanu 1606. - 1825., u: P. Kero, G. Franov-Žıvković, M. Kero, Glagoljske matice umrlih župe Rodenje blažene djevice Marije u Pašmanu 1606. - 1825., VII - XXXII., Zadar, 2015.

FrANov-Žıvković, Grozdana, Lukoranski glagoljski kodeksi, Glasilo Udruge glagoljaša Zadar Slovo Rogovsko, br. 3, Zadar, 2015., 12 - 16. 
Granić, Miroslav, Martinović, Denis, Plemstvo kraljevine Dalmacije 1814.1918., Zadar, 2018.

Jelić, Roman, Stanovništvo Zadra u drugoj polovici XVI i početkom XVII stoljeća gledano kroz matice vjenčanih, Starine, Zagreb, 1959., 349 - 509.

JELIĆ, Roman, Zadarsko nahodište, Radovi Instituta JAZU u Zadru, 10, Zadar, 1963., 213 - 289

JELIĆ, Roman, Stanovništvo Zadra 1608. godine, Zadar, 1985.

JELIĆ, Roman, Zdravstvo u Zadru i njegovu području, Zadar, 1978.

JELIĆ, Roman, Zdravstvo na zadarskim otocima, Zadarsko otočje, ur. Valentin Uranija, Zadar, 1974., 579-619.

Kero, Pavao, Franov-Živković, Grozdana, Kero, Marija, Glagoljske matice umrlih župe Rođenje blažene djevice Marije u Pašmanu 1606. - 1825., ur. Pavao Kero, Josip Faričić, Zadar, 2015.

Kero, Pavao, Popis glagoljskih kodeksa Zadarske nadbiskupije, 2. izdanje, Zadar, 2015.

Kero, Pavao, Franov-Živković, Grozdana, Kero, Marija, Dvije sukošanske matične knjige umrlih 1608. do 1759., Monumenta glagolitica Archidioecesis Iadertianae, Zadar, 2018., ur. Pavao Kero, Josip Faričić, 7 - 23.

Kero, Pavao, Franov-ŽIvković, Grozdana, Pet glagoljskih matica krštenih župe Uznesenja B. D. M. na Olibu 1565. - 1668., Zadar, 2011.

Kero, Pavao, Franov-ŽIvković, Grozdana, Četiri glagoljske matice vjenčanih župe Uznesenja B. D. M. na Olibu 1566. - 1681., Zadar, 2011.

Kero, Pavao, Franov-Živković, Grozdana, Tri glagoljske matice umrlih župe Uznesenja B. D. M. na Olibu 1613.-1771., Zadar, 2011.

Kero, Pavao, Franov-Živković, Grozdana, UšalJ, Svetko, Glagoljske matice krštenih i vjenčanih župe Gospe od Ružarija u Grusima 1613. - 1824., Zadar, 2014.

Klaić, Nada, Petricioli, Ivo, Zadar u srednjem vijeku, Zadar, 1976.

KLEN, Danilo, Galijoti i brodovi na vesla u našoj prošlosti, Pomorski zbornik, sv. 1, ur. Grga Novak, Vjekoslav Maštrović, Zagreb, 1962., 136 - 139.

Kovačıć, Slavko, Katedralne škole u Dalmaciji pod mletačkom vlašću od konca 16. do početka 19. stoljeća prema biskupskim izvještajima Svetoj Stolici, Croatica christiana periodica, br. 27, Zagreb, 1991., 59 - 87.

Ljuвić, Šime, Commissiones et relationes Venetae, 1433-1527., tom I, Zagreb, 1876.

Madunić, Domagoj, Mjera grada: Zadarski popis stanovništva 1527. godine, Povijesni prilozi, 36, Zagreb, 2009., 23 - 62. 
Nani Mocenigo, Mario, Storia della marina veneziana: da Lepanto alla caduta della Repubblica, Roma,1935.; reprint: Venezia, 1995.

Novak-SAmbrailo, Maja, Matrikula bratovštine sv. Jakova iz Galicije u Zadru, Radovi Instituta JAZU u Zadru, Zagreb, 1972., 5 - 31.

Novak-Sambrailo, Maja, Plemići, građani i pučani u Zadru (XV-XVII st.), Radovi Zavoda za povijesne znanosti HAZU u Zadru, 19, Zadar, 1972., 167 - 186.

Novak, Maja, Zadar glavni grad Mletačke Dalmacije i Albanije, Radovi Instituta JAZU u Zadru, 11-12, Zadar, 1965., 119 - 199.

Petricioli, Ivo, Škrinja sv. Šimuna u Zadru, Zagreb, 1983.

RAdolA, Tea, Stanovništvo Barbana u matičnim knjigama XIX. stoljeća, diplomski rad, Sveučilište Juraj Dobrila, Pula, 2016.

Raukar, Tomislav, Petricioli, Ivo, Švelec, Franjo, Peričić, Šime, Zadar pod mletačkom upravom, Zadar, 1987.

SABALICH, Giuseppe, Curiositá storiche Zaratine, Zadar, 1906.

StAgličı́, Marija, ŠTok, Sanja, Crkva i samostan sv. Marcele u Zadru, Prilozi povijesti umjetnosti u Dalmaciji, vol. 36, br. 1., Split, 1996., 187 - 204.

Strgačić, Ante, Inventar fonda matičnih knjiga Državnog arhiva u Zadru, Predgovor Inventarnoj knjizi.

Traljić, Seid, Trgovina Bosne i Hercegovine s lukama Dalmacije i Dubrovnika u XVII i XVIII stoljeću, Pomorski zbornik, I, Zagreb, 1962., 341 - 371.

TrAlJIĆ, Seid, Mletačko-tursko susjedstvo na zadarskoj krajini XVII. stoljeća, Radovi Instituta JAZU u Zadru, sv. 4-5, Zagreb, 1959., 409 - 424.

TraljIĆ, Seid, Zadar i turska pozadina od XV. do potkraj XIX. stoljeća, Radovi Instituta JAZU u Zadru, sv. 11-12, Zadar, 1965., 203 - 227.

Traljić, Seid, Tursko-mletačke granice u Dalmaciji u XVI. i XVII. stoljeću, Radovi Instituta JAZU u Zadru, sv. 20, Zadar, 1973., 447 - 458.

Traljić, Seid, Vrana i njezini gospodari u doba turske vladavine, Povijest Vrane, Političko, kulturno i privredno značenje Vrane kroz stoljeća, Zadar, 1971., 343 - 378.

Usmiani, Ante, Sudbina zadarske galije predviđene za bitku kod Lepanta, Lepantska bitka - udio hrvatskih pomoraca u lepantskoj bitki 1571. godine, Zadar, 1974., 105 - 118.

Skupnost arhivov Slovenije Vodniki I zvezek; Vodnik po matičnih knjigah za območje SR Slovenije, Ljubljana, 1972. 


\section{Grozdana FRANOV-ŽIVKOVIĆ}

\section{ZADAR REGISTER OF DEATHS 1597-1617}

\section{SUMMARY}

Based on the data recorded in the register of deaths from 1597 to 1617, a study of the structure of Zadar society was carried out through the analysis of individual social class groups (patricians, clergy, members of the Venetian military and civil administration, citizens, commoners) and the analysis of professional groups, soldiers, fishermen, sailors, farmers and others). Rare causes of death were listed, which were recorded only for violent deaths. Burials took place in most of Zadar's churches (24), with military personnel primarily buried in the church of St. Frane. In contrast, the nobility was buried chiefly in the churches of St. Frane, St. Marija, St. Dominic. Commoners and clergy were buried in all the churches evenly, commoners depending on the part of town where they lived, while the clergy were buried in the churches they served. A brief overview is given of the historical circumstances and the manner of keeping the registers after the Council of Trent.

We concluded that the most significant number of inhabitants of Zadar at the time of keeping this register from 1597 to 1617 were from Zadar (although in this category, there are some people whose origin was not registered). The fewest people came from the area of Lika and Banovina. At the same time, the rest of the population were people from other Venetian regions and the people from the Zadar hinterland and islands. From these other Venetian areas, primarily members of military personnel came. In contrast, the population from the Zadar area came to live and work in Zadar, most of them permanently settling there.

Keywords: Register of deaths, Zadar, population structure, burial places, late 16 th and early 17 th century. 